Portland State University

PDXScholar

10-25-1994

\title{
Fort Clatsop National Memorial: A Study in Historic Preservation
}

Kelly June Cannon

Portland State University

Follow this and additional works at: https://pdxscholar.library.pdx.edu/open_access_etds

Part of the History Commons

Let us know how access to this document benefits you.

\section{Recommended Citation}

Cannon, Kelly June, "Fort Clatsop National Memorial: A Study in Historic Preservation" (1994).

Dissertations and Theses. Paper 4719.

https://doi.org/10.15760/etd.6603

This Thesis is brought to you for free and open access. It has been accepted for inclusion in Dissertations and Theses by an authorized administrator of PDXScholar. Please contact us if we can make this document more accessible: pdxscholar@pdx.edu. 


\section{THESIS APPROVAL}

The abstract and thesis of Kelly June Cannon for the Master of Arts in History were presented October 25, 1994, and accepted by the thesis committee and the department.

COMMITTEE APPROVALS:

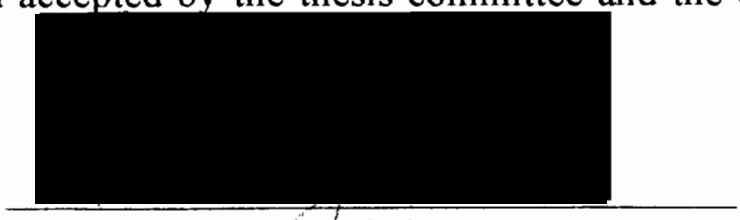

David A. Johnson, Chair

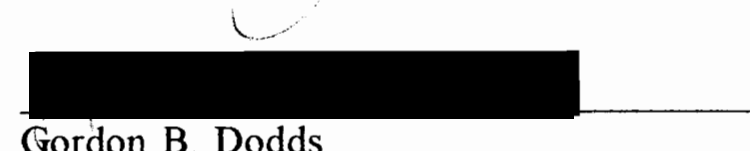

Gordon B. Dodds



Friedrich E. Schuler

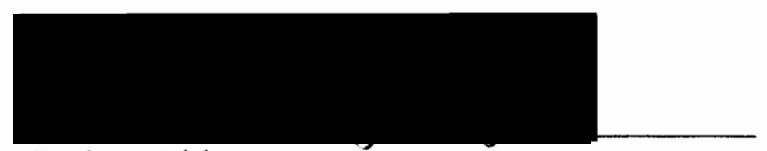

Carl J. Abbott

Representative of the Office of Graduate Studies

DEPARTMENT APPROVAL:



David A. Johrson, Chair

Department of History

ACCEPTED FOR PORTLAND STATE UNIVERSITY BY THE LIBRARY

by

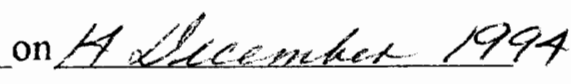




\begin{abstract}
An abstract of the thesis of Kelly June Cannon for the Master of Arts in History presented October 25, 1994.
\end{abstract}

Title: Fort Clatsop National Memorial: A Study in Historic Preservation

Fort Clatsop National Memorial is a unit of the National Park Service in Clatsop County, Oregon. The memorial was established by an Act of Congress in 1958 to commemorate the culmination and $1805-1806$ winter encampment of the Lewis and Clark Expedition. The memorial centers around a replicated fort structure.

The purpose of this thesis is to examine the process of preserving historic sites under the National Park Service (NPS) by examining the history of Fort Clatsop National Memorial. Through this examination it is possible to understand the realities of the national preservation system and the ideals fostered by those involved in the system.

The Fort Clatsop site became the subject of folk history in Clatsop County, which culminated in a community movement for national recognition. During the community sponsored 150th anniversary celebration of the Expedition, local civic groups built the existing fort replica. The management needs of the replica caused the site owner, the Oregon Historical Society (OHS), to actively pursue national recognition. 
To achieve the creation of a national memorial, OHS and community members enlisted the help of Senator Richard L. Neuberger. Senator Neuberger drafted and successfully sponsored legislation for the creation of the memorial.

Since the memorial's creation in 1958 , the site has been under the management of the National Park Service (NPS). As a historical, commemorative unit, the NPS is responsible under the 1935 Historic Sites Act for presenting the history of the Expedition to the public. Such historic interpretation includes the use of costumed demonstrations, exhibits, and other interpretive media. Fort Clatsop also represents the ideals of education and inspiration in NPS interpretive policies.

In conclusion, the examination of Fort Clatsop illustrates factors involved in the creation of historic sites within the NPS and how private individuals and Congress affect the selection of historic sites for preservation. While illustrating how the private sector and Congress can decide what historic sites are preserved under the park system, this examination also illustrates how the park system handles those sites placed under its management and how NPS management helps shape public memory. 
FORT CLATSOP NATIONAL MEMORIAL

A Study in Historic Preservation

by

KELLY JUNE CANNON

A thesis submitted in partial fulfillment of the requirements for the degree of

\section{MASTER OF ARTS}

in

HISTORY

Portland State University

1994 


\section{CONTENTS}

$\begin{array}{ll}\text { Acknowledgments } & \text { iii }\end{array}$

Introduction: Fort Clatsop and Historic Preservation 1

$\begin{array}{ll}\text { Chapter One: The Fort Clatsop Site } & 16\end{array}$

Chapter Two: Legislative Process 41

Chapter Three: Management Goals of the NPS

at Fort Clatsop 56

$\begin{array}{lr}\text { Chapter Four: Interpretation } & 112\end{array}$

$\begin{array}{ll}\text { Conclusion } & 133\end{array}$

$\begin{array}{ll}\text { Endnotes } & 142\end{array}$

$\begin{array}{lr}\text { Bibliography } & 150\end{array}$ 


\section{ACKNOWLEDGMENTS}

This thesis was possible through access to Fort Clatsop National Memorial records and the cooperation of the memorial's past and current staff. I need to thank Gretchen Luxenberg, Pacific Northwest regional historian, for hiring me to produce the administrative history of the park and giving me that access. I also thank David Johnson for recommending me for the job, serving as my advisor, and for calming my anxieties throughout the thesis program. Thanks to my fellow grads, Olivia Alcaire, Rachel Susman, and Terri Theisen, for listening and sympathizing.

I also must thank my family for their support: David for his patience while I worked, grumbled, and fretted; my father, Bill, who read drafts and cheered me on; and most importantly my mom, Janine, who went above and beyond the call of motherhood. She served as my editor, spent two vacations working on this document, and bought me a computer to write the thing on. This thesis would not have been completed without her. 


\section{INTRODUCTION: FORT CLATSOP AND HISTORIC PRESERVATION}

After reaching the Pacific Ocean in November 1805, the Lewis and Clark Expedition chose to move south of the Columbia River to set up a winter camp. They chose a place inland, a campsite that provided access to a freshwater spring and the Netul River (Lewis and Clark River) for transportation, access to the coast for salt production and possible encounters with trade ships, had promising elk populations, and was removed from the harsh weather carried in from the Pacific Ocean. At that site, the party quickly constructed a temporary wood structure, which they named Fort Clatsop for the neighboring American Indian culture. For three and one-half months, the members waited out the rain, hunting, making salt, compiling their journals and maps, and preparing for the journey back home. One hundred and fifty years later, the residents of Astoria and Clatsop County, Oregon, celebrated the Corps of Discovery by building a replica of their winter quarters on the site long referred to as the "site of Old Fort Clatsop".

It is this community sponsored and built replica that is the center of Fort

Clatsop National Memorial, a unit of the National Park Service (NPS). Clatsop County residents sought national recognition for the site as early as 1905. Established 
in 1958 , this small park has grown to be one of the largest tourist attractions along the northwestern Oregon Coast. Memorial visitation reached nearly a quarter of a million people in 1992. For thirty-five years, this small park has endeavored to tell the story of the Corps of Discovery and its impact on the Pacific Northwest.

The memorial is located six miles south of Astoria. The site lies along the Lewis and Clark River, south of Youngs Bay and four miles from the Pacific Ocean. The satellite Salt Works site is located 15 miles south of the memorial in Seaside, Oregon. The memorial totals 125.2 acres. Buildings at the memorial include a visitor center containing exhibits, a theater and multipurpose room, the Fort Clatsop Historical Association gift shop, public facilities, administrative offices, and the Fort Clatsop Regional Research Library. There are two employee residence houses and a maintenance shop. Interpretive points of interest include the fort replica, the canoe landing site, the spring site, and the Salt Works site in Seaside. There is a small picnic area with covered tables. Foot trails with natural history interpretive markers connect these points of interest.

Fort Clatsop has very diverse natural resources. The memorial environment contains coastal conifer forest and estuarine wetland habitats, with well over 300 known species of plant and animal life. The climate is very wet, receiving about 75 inches of rainfall per year. The fort and salt works replicas, the natural environment, and the memorial's artifact, natural specimen, and rare books collection are managed as cultural resources. The entire memorial is listed on the National Register of Historic Places (National Register). 
The memorial was established to commemorate the Corps of Discovery's accomplishments and its impact on the development of a young, expanding nation. Through the fort replica, "living history" demonstrations, visitor center exhibits, interpretive markers, and film and slide programs, the memorial presents the history of the expedition and its significance to American and Pacific Northwest history, as well as depicting life at the fort during the winter of 1805-1806.

Historic preservation in America functions primarily as a medium for public commemoration of the historical past. The methods by which Americans select and promote historic sites also facilitates the construction of public memory. However, patriotic values and the desire for commemoration are not the only factors affecting American preservation. This study of the history of the Fort Clatsop site, from EuroAmerican settlement through management policies of the National Park Service, examines historic preservation in America at the site level.

Fort Clatsop illustrates three aspects of twentieth century historic preservation in America. First is the influence of private preservation groups, such as the Oregon and Clatsop County historical societies, in the selection and promotion of local historic sites for preservation. The pride and patriotism expressed by local groups in their heritage has in large part determined which sites have been saved and lost. Second, the development of the memorial's interpretive programs utilized the ideas of the outdoor museum exhibit. Commemoration of the Expedition centers around a handson, replicated house museum. Third, historic interpretation at Fort Clatsop epitomizes the traditional policies the National Park Service follows in presenting American 
history to the public. Developed in the 1930s, when the NPS inherited the nation's historic sites and memorials, interpretation programs were developed not only to educate, but also to inspire.

\section{The Influence of Citizen Groups}

Americans involvement in the preservation of their heritage began with the creation of the United States of America. The first state historical society, Massachusetts, was established in 1789 . One of the first projects of early preservationist America came in 1816 when the City of Philadelphia purchased the Old State House (Independence Hall), saving the building from destruction. The state house also became one of the nation's first restoration projects in 1828 when American architect William Strickland reconstructed the state house tower.

The saving of Independence Hall by the City of Philadelphia is a rare early example of government preservation. Contrary to European nations, which by the mid-nineteenth century had government controlled preservation programs, federal control of preservation in the United States did not begin until the twentieth century. Throughout the nineteenth century, various historical, veterans, and hereditary societies and associations worked to memorialize and preserve their heritage, and private philanthropy often funded early preservation projects. The classic model of citizen participation in preservation is the Mount Vernon Ladies' Association. Led by Ann Pamela Cunningham, the association accomplished what the state of Virginia and the federal government declined to do. In 1858 , the association purchased George 
Washington's Virginia estate to save it from commercial development and decay.

They purchased the estate with funds raised over a five year period. The Mt. Vernon Ladies' Association also represents the face of early preservation movements: largely white, middle and upper class women.

By the 1876 American Centennial, and in particular the centennial exposition in Philadelphia, the preservation movement in America had gained considerable strength. Early preservation in America was born of intense patriotic feelings and centered on historic persons and events considered significant to the founding of the nation, especially George Washington. Groups such as the Daughters and Sons of the Revolution, the Grand Army of the Republic, and the Colonial Dames worked to promote their patriotic values through the placement of monuments and memorials, anniversary celebrations, and sponsorship of history lectures and essays. ${ }^{1}$ By 1876,78 different historical and preservation societies existed. ${ }^{2}$ According to preservationist William Murtagh, the preservation movement evolved from a "growing interest in who we were, where we had been, and what we had achieved as a nation and as a society". ${ }^{3}$ The Centennial highlighted this emotional basis for American preservation and its ideals.

In the East, throughout the nineteenth century, commemoration centered around the birth of the nation and the nation's battlefields. In the West and Midwest, historic preservation centered around various subjects. From the late nineteenth and early twentieth centuries, western preservation sought out prehistoric American Indian sites, sites of Spanish settlement in the Southwest, and the forts and settlements of the fur 
trade, frontiersmen, explorers, and pioneers. ${ }^{4}$

During the early twentieth century, historic preservation moved through stages that witnessed the development of Colonial Williamsburg and Greenfield Village to the development of a federal preservation policy that would essentially direct preservation in America after World War II. The passage of the Antiquities Act of 1906 began federal involvement in the preservation of historic sites by giving authority to the president to set aside and protect prehistoric sites. Sparked by the interests of patriotic preservationists such as John D. Rockefeller, W.A.R. Goodwin, Henry Ford, and NPS Director Horace M. Albright, preservation moved beyond private funding to include government funding under the New Deal job creation programs such as the Civilian Conservation Corps. By presidential executive order in 1933, the National Park Service, created in 1916 to protect and preserve the nation's parks, was given control of the nation's historic monuments, battlefields, and cemeteries previously managed by the Forest Service and the War Department, a transfer that Albright had first campaigned for in $1917^{5}$

In 1935, the Historic Sites Act officially delegated regulation of historic sites in the government's possession to the Secretary of the Interior and the NPS. It also established the Advisory Board on National Parks, Historical Sites, Buildings and Monuments, for the inventory, selection, preservation needs assessment, and possible inclusion of historic sites within the national park system.

The legislation of the 1930s moved preservation from the control of private citizen groups and associations to regulation under federal agencies and legislation. 
With passage of the 1966 National Historic Preservation Act and the creation of the National Trust, a regulated system of preservation, control, and funding under the authority of the Department of the Interior and the National Trust was established. Under provisions of the 1966 act, the Secretary of the Interior requested the creation of state appointed liaisons to help fulfill the needs of the new legislation. This resulted in the creation of state historic preservation offices, which work in coordination with the Department of the Interior. ${ }^{6}$

This system of regulated preservation under federal and state government is not unaffected by the desires of private citizens' organizations or societies, however, and Fort Clatsop is a prime example of the continued involvement of local bodies in the preservation of historic sites. After 1933, the first history staff of the National Park Service worked in conjunction with the advisory board to create standards for determining those sites to be preserved under federal recognition. In reality, sites added to the system between the 1930 s and the 1950 s were done in a hodge-podge manner, with limited success in regulating which sites received national recognition and management and which did not.

When regulation of historic sites was transferred to the Park Service in 1933 , the federal government and the Park Service dealt with an influx of proposals from the public and different organizations for various national historic sites. Congress faced over sixty legislative proposals for national parks and historic sites in just the 1st session of $1935 .^{7}$ The diversity of the subjects proposed, and the variety of their importance to the nation, was extreme, ranging from the birthplaces of local heroes to 
sites along historic trails. ${ }^{8}$ However, while the NPS set guidelines for the selection of historic sites to be included in the park system, it does not control the creation of historic sites as national park units.

The authority to create new park units lies with Congress, not the NPS. With the authority to create historic sites, Congress and the public have retained the ability to tell the park service what they believe to be of national significance. Pork barrel parks have been an issue since the beginning of the national park system and the first directors of the NPS tried to combat the creation of such parks as best they could. ${ }^{9}$ This has sometimes forced the park service to consider not only the appropriateness of a suggested site, but also their chances of being able to avoid the site if they did not find it appropriate. ${ }^{10}$

Such was the case with Fort Clatsop. The first attempt at legislation for a national monument at the site occurred in 1905 , at the time of the Lewis and Clark centennial. In 1937, the advisory board completed a survey of Oregon historical sites in conjunction with the Oregon state parks board. In this survey, the advisory board recommended state management for the Fort Clatsop site and it remained in private ownership under the Oregon Historical Society (OHS). After the 150th anniversary of the Lewis and Clark Expedition in 1955, when the fort replica was constructed by local civic groups, OHS was left with management of the site and its improvements. Members of the society valued the Fort Clatsop site as a historical landmark, but economic realities forced the society to look for relief in the site's management. For that relief, they turned to the federal government and Oregon Senator Richard 
Neuberger to achieve national recognition for the site.

The NPS followed the 1937 advisory board recommendation and was not interested in the creation of Fort Clatsop as a NPS unit. Were it not for the efforts and strategy of Senator Neuberger, Fort Clatsop today would probably be under either state or local management. Senator Neuberger not only responded to the desires of his constituents, he also had personal feeling for the Fort Clatsop site and the history of Oregon. Neuberger utilized the system of historic preservation and its standards for recognition to his advantage and would successfully legislate the creation of Fort Clatsop National Memorial, despite NPS objections.

\section{The Outdoor Museum}

Ultimately, Fort Clatsop National Memorial preserves a piece of land associated with a historic event. This preservation of an area differs from the usual historic building, district, battlefield or archeological site traditionally sought out by preservation movements. In terms of the preservation structure at work in America, the memorial fits best within the concept of the outdoor museum.

An outdoor museum is defined as a "restored, re-created, or replica village site in which several or many structures have been restored, rebuilt, or moved and whose purpose is to interpret a historical or cultural setting, period, or activity". ${ }^{11}$ This differs from the historic house museum in that the latter is developed around a historic structure and is usually done as a means of saving the structure involved. Although outdoor museums generally consist of more than one building, the concept utilized by 
outdoor museums of re-creating a historic setting for educational purposes matches the approach that the National Park Service has taken in managing Fort Clatsop.

The idea for the outdoor museum was developed in Sweden by Artur Hazelius and became the primary method of preservation throughout the Scandinavian countries, where approximately 800 such places exist. ${ }^{12}$ Perhaps it is only coincidence that Clatsop County has a large Scandinavian population which was heavily involved in the development of the fort replica and its designation as a national memorial.

The first and most famous outdoor museums developed in America during the period 1926 to 1950. Colonial Williamsburg, Greenfield Village, Deerfield Massachusetts, and Sturbridge Village were all created through the dedication and philanthropy of individuals. The philosophy behind these outdoor museums was education with preservation ideals falling secondary. ${ }^{13}$ Williamsburg was the exception, where John D. Rockefeller, Jr. took great pains in consulting restoration professionals. The Williamsburg staff took great pains to achieve faithful reconstruction. In the development of a preservation profession during the 1930 s, the park service and Colonial Williamsburg embodied this new profession. The primary motivation of Williamsburg was expressed in its motto "That the Future May Learn from the Past". Greenfield Village, created by Henry Ford, was intentionally created to educate. Ford desired historic houses and objects to convey his message, but gave little regard to the value of historical accuracy in preservation. This is evidenced by his removal of historic structures from their original locations. ${ }^{14}$

The Fort Clatsop replica and memorial falls into the category of an outdoor 
museum for two reasons. First, the building is replicated and no archeological evidence has yet been found to substantiate the site. Second, the replica is used as a backdrop for educating the visitor about the Lewis and Clark Expedition. While the documentary evidence is strong enough to support that the memorial does contain the original site of Fort Clatsop, emphasis has been shifted from the actual historic site to the education of the public.

\section{Not Only To Educate, But To Inspire}

Currently, the National Park Service controls or influences most of the historic sites across the nation, either through direct management as a park unit or through federal recognition on the National Register. Perhaps no other group has as much control over public memory than the NPS. Since the 1930s, the standards developed by the National Register program and the National Trust have determined a framework to define which sites deserve national recognition. While Congress and public proponents of certain historic sites have challenged or ignored those standards, especially from 1933-1970, they have formed the basic structure of site selection and debate.

NPS Director Horace M. Albright came into his duties as director in 1928 with the goal of gaining federal historic site management under the NPS. Several factors were in his favor. The renewed interest across the nation in historic sites, stirred by World War I, brought heightened awareness to preservation causes. Second, the onset of the Great Depression and the Roosevelt administration's reorganization policies 
facilitated the transfer of historic properties for which Albright had campaigned.

Third, the influx of government spending to create jobs facilitated many conservation and preservation projects throughout the NPS.

The first historian employed by the NPS, Verne E. Chatelain, left a lasting impression on park service history and interpretation. Hired by Albright in 1931, Chatelain facilitated the transfer of federal historic sites by testifying to the needs of proper federal preservation and interpretation of the sites for the public. These sites, he argued, needed proper management by historians trained to do the job and the National Park Service was just the agency to provide that service.

Chatelain was dealt the task of creating a professional historical staff for the NPS. The Great Depression left many historians unemployed and they found work in the growing ranks of the park service. In a 1961 interview with Charles B. Hosmer, Jr., Chatelain described his first task as transforming the historian into the park service man, training him to present history to the public. ${ }^{15}$ Essentially, Chatelain created the Ranger Historian. Under his guidance, NPS historical policy was designed to educate the public and in his words "breathe the breath of life into American history for those to whom it has been a dull recital of meaningless facts, to recreate for the average citizen something of the color, the pageantry, and the dignity of our national past". ${ }^{16}$ In essence, the National Park Service in 1933 was given ownership of the symbolic past of America and zealous historians like Chatelain were ready to take on that responsibility.

The ideals expressed by Chatelain during the expansion of the NPS were 
revived in 1956 through a national program of park revitalization called Mission 66.

The re-affirmation of nationalistic values in NPS interpretation were in part a response to the Cold War and a heightened sense of American patriotism. The values placed on the inspiration of the public through its national heritage coincided with the development of Fort Clatsop. In 1958, NPS Region Four historian John Hussey, who would be influential in the development of the memorial, gave a presentation during a training program at Yosemite National Park called "The Role of History in the National Park System". Hussey stated that historic sites "inspire patriotism and love of country by recalling the events and ideals which made our nation great; they remind us of our common social, cultural, and spiritual background, of that national history which forms perhaps our strongest single social bond". ${ }^{17}$ Hussey believed that historic sites were the vehicles which inspired true patriotism through a recognition of American courage, sacrifice, and determination.

The values expressed by Hussey regarding interpretation can still be felt in the current themes of interpretation at Fort Clatsop. Memorial interpretation is designed not only to educate the public about the Expedition and its political aspects, but also to demonstrate to the public the fortitude of the Expedition in hopes of inspiring them in their own everyday lives. ${ }^{18}$

\section{Public Memory}

The Lewis and Clark Expedition has inspired commemoration across the nation. The route followed by the Expedition is a nationally recognized historic trail, 
it is memorialized at Fort Clatsop and as a part of the Jefferson National Expansion Memorial in St. Louis. Many times Americans have retraced the route of the Expedition. The centennial of the Expedition was celebrated at the 1905 World Fair, which included a replica of Fort Clatsop. If historic preservation has traditionally centered around important historical events and individuals, the Expedition certainly fits in that category. Sometimes cited as the Expedition which claimed the Oregon Country for the United States, the Expedition epitomizes the qualities of the American frontier explorers: courage, science, fortitude.

Historian John Bodnar has argued that public memory emerges from the intersection of official and vernacular cultural expressions, the intersection of cultural leaders and ordinary people. ${ }^{19}$ Public memory is born of the struggle between these two bodies of society. In the case of Fort Clatsop, local vernacular culture kept the memory of Fort Clatsop alive for 150 years, from 1811 until 1958. Long after any remnants of the original structure disappeared, residents took great pride in the fact that Lewis and Clark wintered nearby. The commemoration of the Lewis and Clark Expedition also fit the needs of official culture in the promotion of American heritage. For OHS, the meeting of official and vernacular culture released the society from a management burden without forfeiting their duty to preserve the state's historic sites.

Preservation and commemoration of historic sites is an expression and continuation of public memory. Public and private societies and individuals work to preserve historic sites in order to educate future generations about that aspect of their heritage. Preservation also promotes values associated with certain historic events and 
individuals. In the case of Fort Clatsop, vernacular or popular culture influenced recognition by the official culture of politics. Under NPS interpretation, which functions as a blend of official and vernacular cultures, Fort Clatsop has been used as an effective education tool, educating park visitors about the Lewis and Clark Expedition.

Chapter one of this thesis discusses the characteristics of the site, its historical significance, and its identification and development by Oregonians. Chapter two discusses the legislative process through which the site was transferred from private to federal ownership and management. Chapter three discusses the management policies, structures, and concerns of the NPS at Fort Clatsop. Chapter four discusses the educational interpretive programs at the memorial and how they have been shaped by NPS interpretive policy. The examination of Fort Clatsop provides an awareness of the realities of historic preservation, its motivations, and its role in the facilitation of public memory. 


\section{CHAPTER ONE: THE FORT CLATSOP SITE}

Understanding the history of the Fort Clatsop site, its identification and development by Oregonians, provides a view into the process by which an area becomes identified as historically significant. Almost immediately after the Expedition headed east, a record of visitation to the site began. The Clatsop Indians and then the incoming furtrappers and settlers created a public memory of the site that continued after the remains of the fort disappeared. This public memory influenced the activities of local historical societies and civic groups, who considered the site worthy of preservation for future generations. This chapter chronicles the activities which give the site its historic value through its identification and commemoration by the public prior to its inclusion in the National Park System.

\section{Lewis and Clark at Fort Clatsop}

When the Corps of Discovery arrived at the Pacific, the expedition consisted of thirty-three people and one dog. Of the thirty-three, most were FrenchCanadians and Americans. Tossaint Charbonneau and his American Indian wife, 
Sacagawea, were hired as interpreters for the expedition and were accompanied by their infant child. William Clark's slave, York, was also a member of the expedition. The members of the Expedition voted to move down the Netul River (the present day Lewis and Clark River) to a camp site selected by Captain Lewis on December 7, 1805. Work clearing the site for a fort began immediately.

By December 10, the foundations for the rooms were laid and by December 14 , they had finished the room walls and had begun roofing the meat house room. All roofing was completed by December 24 and the walls were "chinked" with mud. The captains moved into their room on December 23, the rest of the expedition moving in on Christmas Eve and Day. The rooms had puncheon floors and bunks. After Christmas, they built chimneys in the living quarters and installed pickets and gates. On December 31, they built a sentinel box and dug two "sinks". The journals do not give a detailed description of the fort. Two conflicting floor plans exist, one by Sergeant Ordway and one by William Clark. Precedence has traditionally been given to Clark's documentation. ${ }^{1}$ By Clark's description, the fort was fifty feet square with two parallel cabins. One cabin contained 3 rooms, each with a central fireplace, which were the enlisted men's quarters. The opposite cabin contained four rooms, two or three with fireplaces. One room was the meat house, which had a fireplace and door with a lock. This side also contained the captains' room, which had a fireplace with an external chimney. The Charbonneau family had a room on this side as well. Two gates were installed, one at each end of the parade ground. One was the main gate, which was locked at night. At the 
opposite end, the second gate was used to access the spring for water or other necessary trips outside.

The expedition party stayed at Fort Clatsop until March 23, 1806, when they set out for their return journey. During their stay, hunting was the main occupation of the enlisted men, and they were often away from the fort overnight or for a few days. It was a continual process to feed so many people. The party lived primarily on elk, consuming also deer and fish, wapato roots, some water fowl and beaver, dog, and the rare treat of whale blubber. By the time they had selected the site of Fort Clatsop and built their quarters, the damp climate had rotted their clothing, tents, and other hide based goods. Elk and deer hides brought in from hunting were used to make new clothing, moccasins, bags, and covers for their luggage.

A group from the expedition party was sent to the coast to extract salt from sea water, leaving Fort Clatsop on December 28, 1805. They established a camp site near a Clatsop village at present day Seaside and continued making salt around the clock until their return to Fort Clatsop on February 21, 1806.

A system of guard duty was established at Fort Clatsop, occupying a sergeant and three enlisted men round the clock. The guard was in charge of announcing approaching groups of Indians, opening and closing the gates, tending the meat house fires and supply, periodically checking the condition of the canoes at the landing site, and bringing in wood for the fireplaces in the captains' quarters. The captains occupied their time preparing their journals and maps. Lewis' journal from Fort Clatsop ended a three month hiatus from journal keeping and provides 
some of his best ethnographic and botanical information from the expedition. Both captains made trips to the coast, one to procure some blubber and oil of a beached whale.

The area around the mouth of the Columbia River, where the Corps of Discovery spent the winter of $1805-1806$, was originally home to the Lower Chinookan peoples. More specifically, the site of their fort was in the territory of the Clatsops. The name Chinookan applies to the linguistic group made up of the different tribes or villages from the mouth of the Columbia up river to The Dalles. Within this group, the Chinookan are divided into the Lower and Upper Chinookan, each containing different villages and some dialect variations. European and American traders derived the name Chinook from a Salish name for a specific village on Baker Bay. Eventually, all the villages on the north side of the Columbia River, inland about 15 miles from Grays Bay and north to the top of Willapa Bay, became known as the Chinook proper. ${ }^{2}$ The Clatsops, who probably shared the same Chinookan dialect as the Chinook proper, lived on the south side of the Columbia, from Cape Adams to Tongue Point and south along the coast to Tillamook Head. The Chinook proper and the Clatsops are the two primary members of the Lower Chinookan peoples. Members of the various lower Chinook villages kept the expedition busy on a regular basis bartering, trading, and exchanging information. The cultural exchange between the Expedition and the Chinookan people provided some of the richest documentation of the Chinook prior to EuroAmerican settlement. The relationship between the Expedition and the 
Chinookan villages is featured prominently in memorial interpretive programs and exhibits.

The Lower Chinookan were fishers, gatherers, and hunters. Their diet included salmon and other fish, various berries and roots including the wapato root and the salal berry, elk, deer, waterfowl, small furred mammals like beaver and rabbits, and occasional whales and sea lions. ${ }^{3}$ Hunting and gathering also supplied materials for clothing and essential Chinookan household items. They lived in villages of semi-permanent cedar houses, moving to established fishing camps during the peak fish runs. The number of houses per village varied, each house usually home to a patrilocal extended family of around 20 individuals. The village was the primary social unit and was linked to other villages by ties of trade and kinship. The Lower Chinookan were expert canoe builders, carving as many as six different functional styles from cedar logs. ${ }^{4}$ The canoe was their main mode of transportation and, owing to their strong reliance on the ocean and river for their subsistence, were highly valued pieces of property. Lewis and Clark fretted on many occasions about the unreasonable prices the Clatsops asked for their canoes.

The Pacific Northwest Indian groups were members of a highly developed trade system and the Lower Chinookans were definitely a part of that system.

Dentalium shells from Vancouver Island were a primary currency item among the Chinook and their trade partners. ${ }^{5}$ Trips up the Columbia to trade markets were common. As European and American traders arrived, including Lewis and Clark, this trade system was well entrenched and the different Indian groups tried to 
incorporate these new trade partners into the existing system.

Generally speaking, the expedition party was miserable while at Fort Clatsop. Fleas tormented them and it rained almost every day they were there. The weather was usually grey and wet, which made them disagreeable. Illness abounded during the stay, mostly in the form of colds, fevers, and muscle strains contracted while tracking, hunting, and carrying game in rough, damp terrain often miles away from the fort. Venereal disease also required medical attention. Their diet was usually less than desirable owing to the dampness, which quickly spoiled their meat. Their general discomfort and the movement of elk herds persuaded the expedition to leave on March 23, 1806, rather than the April 1 departure date the captains had established earlier.

\section{Visitation and Settlement}

On March 22, 1806, Lewis recorded in his journal the visit of Chief Comowool and three Clatsops. He states "to this Chief we left our houses and furniture". ${ }^{6}$ According to descendants of Comowool, he used the fort during hunting season for several years after the expedition left. ${ }^{7}$ Beginning with the 1811 arrival of John Jacob Astor's Pacific Fur Company and the establishment of Astoria, a record of visitation to the site by American and European traders, explorers, and settlers began. On October 2, 1811 , Gabriel Franchere, a member of the Pacific Fur Company, reported visiting the ruins of the fort and seeing a pile of rough unhewn logs. A second trip was made by Ross Cox in May or June 1812 . He noted that 
logs from the fort were still standing and marked with the names of several of the party.

On 1813, after the outbreak of the War of 1812 and the loss of their annual supply ship, the Pacific Fur Company sold out to the North West Company. Fort Astoria was taken over by the British and renamed Fort George. ${ }^{8}$ In 1813 Alexander Henry of the North West Company and a captain of the British Royal Navy made a canoe trip to the Fort Clatsop site. There they found two Clatsop houses at the site, saw the remains of the fort, and reported willows growing up inside the remains. They reported that the Clatsops had cut down and used a good portion of the wood. Eight years later, an 1821 congressional report on settlement of the Oregon country stated that the fort remains could still be seen. ${ }^{9}$ Various other travelers and settlers took the time to visit the site, and their documentation provides a record of the site's condition over time. ${ }^{10}$

In 1849, S.M. Henell of Astoria attempted to claim land at the site of Fort Clatsop through an Oregon Provisional Government donation land claim. The next year, however, Thomas Scott jumped Henell's claim through the federal government's 1850 Donation Act. Scott traded the property shortly thereafter to Carlos Shane. Shane built a house a few feet from the remains of the fort. In 1852 or 1853, Carlos Shane's brother, Franklin Shane, moved to the site and in 1853 Carlos Shane moved up river and transferred the site to Franklin. The claim consisted of approximately 320 acres along the west bank of the Lewis and Clark River, and included the fort site and the site along the river bank believed to be the 
canoe landing site, where the Corps moored its canoes. In 1852, Richard Moore wanted to build a mill at the canoe landing site. An agreement was reached between Shane and Moore, resulting in the movement of Shane's boundary slightly north so that Moore could claim the landing site. ${ }^{11}$ Moore built the mill and from 1852 to 1854 the area around the mill was logged and lumber sent by boat from the landing site to San Francisco. During this time, Shane put in an orchard on his property. In 1853 , Fort Clatsop was its own voting precinct with 56 votes polled. $^{12}$ In 1854 , the mill closed and Shane refiled papers for his claim, reclaiming the landing site in his property. ${ }^{13}$ Donation Certificate number 5001 for the site was issued to Franklin Shane in 1857. The claim was 320.5 acres, stretching about half a mile along the west bank of the river and extending about a mile inland.

Shane died between 1860 and 1867 and his property was inherited by his two daughters. In 1872, the husband of Mary Shane, William (Wade) Hampton Smith, was given title to the half of the Shane claim that contained the Fort Clatsop site. Smith built a new house on the property, the house Carlos Shane built having reportedly burned down. William Smith, Mary, and their children lived at the site until 1880 , when they moved to Portland.

One of William Smith's sons, Harlan C. Smith, returned to the Fort Clatsop site during the summer of 1957 , and on July 6,1957 , conducted an interview with National Park Service officials about his childhood at the site. Harlan was 2 years old when his family moved to the site in 1872 and his father built their house. They lived at the site for 8 years. While living at Fort Clatsop, Harlan remembered 
his father was postmaster for the Fort Clatsop post office, distributing mail out of their home. His father also operated a brick manufacturing business for awhile, utilizing the clay deposits in the area. According to Smith, his father built the road from Fort Clatsop to the Clatsop Plains under contract with the Oregon Steam and Navigation Company.

Harlan Smith was able to share his memories of the site as well as his mother's. His mother had spent a good deal of her childhood at the site. She remembered seeing the ruins of Fort Clatsop and recounted to Harlan where they were. She also told Harlan that a decaying, half buried log, running east-west along the north edge of their house, was the last remaining timber of the fort ruins. ${ }^{14}$

When the Smiths moved to Portland in 1880, the Joseph B. Stevenson family, who had been the Smiths' neighbors, moved into the Smith house and rented the property. Over several years, one of Stevenson's occupations at the site was making and selling charcoal.

The canoe landing site continued to be used in other ventures. During the summers of 1860-1862, the United States Revenue Service docked their cutter for maintenance at the landing. ${ }^{15}$ The landing site had also become a convenient stop for tourists traveling to the coast. Travelers would take ships from Portland or Astoria to Fort Clatsop and then take a carriage or horse to Seaside. In 1862, the Oregon Steam and Navigation Company established a regular summer service from Portland to Fort Clatsop and in 1875, W. H. Smith sold 5 acres, containing the canoe landing site, to the company. ${ }^{16}$ While the Stevensons were tenants at Fort 
Clatsop, they ran a carriage service from the landing to Seaside. By 1900, however, new routes of transportation to fit the needs of increasing numbers of tourists ended the Fort Clatsop route. The Oregon Steam Navigation Company had become the Oregon Railroad and Navigation Company, and continued to own the five acres at the canoe landing.

Another commercial development at the Fort Clatsop site resulted from the discovery of significant clay deposits. In 1887, Mary Shane Smith sold half of the clay and mineral rights on the Shane claim to the Oregon Pottery Company. ${ }^{17}$ Clay and mineral rights at the site were bought and sold several times during the next thirty years. From 1887 until 1920, clay was apparently extracted from the area southwest of the three acres obtained as the fort site in 1900 by the Oregon Historical Society. ${ }^{18}$

During the period from 1806 to 1899 , the site of Fort Clatsop became generally known to the local population. The Clatsops certainly remembered the site and, from 1811 until 1850 , remains of a $\log$ structure at the present site were considered to be the remains of Fort Clatsop and pointed out as such to visitors and arriving settlers. After the commencement of agricultural production and other economic pursuits obliterated those log remains, the site remained known as Fort Clatsop to the local population through oral tradition. Settlers who had seen the remains pointed out the site to their children. 


\section{Identification of the Site}

In 1899, a writer for the Northern Pacific Railway named Olin D. Wheeler arrived in Clatsop County. He was attempting to trace the route of Lewis and Clark, and this inevitably brought him to Astoria in search of Fort Clatsop. Wheeler assembled a group of local people who knew the site to take him there around August 28-29, 1899. In his party were four longtime Astorians and the grandson of Chief Comowool, Silas B. Smith, as well as a representative of the Oregon Historical Society and a photographer. The five men were in general agreement as to the location of the site, which they pointed out to Wheeler. A series of photographs were taken of the men at the site. However, Wheeler did not record the exact location of the site. The only evidence of their identification of the site are those photographs.

Due to Wheeler's lack of documentation, the process of identification had to be repeated in June 1900 , when the Oregon Historical Society decided to identify the site and appropriately mark it. This time, the identification party consisted of Silas B. Smith, Carlos Shane, Preston W. Gillette, and two members of the society. Carlos Shane, of course, was the first settler at the site. Preston W. Gillette had settled a land claim a couple of miles away. No surveyor accompanied them. The men pointed out where they remembered seeing the southwest corner of the fort and placed a stake in the ground to mark that corner. From that corner, they then placed three more stakes where they speculated the other three corners of the fort's stockade would have been. The historical society then took depositions from the 
settlers, who described when they saw the fort remains, what they saw, and where they saw them. Key to Shane's testimony is his recollection about the cabin size and layout. He stated that there were two cabins parallel to each other, about 15 feet apart, each cabin being about 16 by 30 feet. ${ }^{19}$ Significantly, this description roughly follows the floor plan of Fort Clatsop that William Clark recorded in his journal. However, Clark's plan was not made public until 1904. The correspondence of Shane's observations with Clark's plan is perhaps the strongest evidence to substantiate that the site pointed out was indeed the site of Fort Clatsop.

Also in these depositions, Carlos Shane admitted to trying to burn the remains after building his house so he could use the land. Gillette reported first seeing the ruins in 1853 , and that the $\log$ ends were burned, so Shane was not entirely successful. The fact that Shane tried is a testimony to the fact that the site was important enough to be sought out and visited by passersby and other locals, but it was not important enough to those using the land to try and preserve them in any way. The testimony of Shane, Gillette, and Smith convinced the historical society that the site had been permanently fixed, and in 1901 the society purchased three acres that contained the fort site.

\section{OHS Management of the Site}

Not until 1912 did the historical society commemorate the site with the placement of a bronze marker. By then, the stakes that had been placed in 1900 
could not be found, and, since the placement of the first stake was not recorded by a surveyor, it is not clear how they determined where to put the marker ${ }^{20}$ In 1928 , the society purchased two additional acres on the south side of the three acres, which contained the spring thought to be used by the Expedition party during the winter of 1806 . The society also installed a flagpole with the bronze tablet on a cement base and cleared away vegetation around the marker. Clatsop County improved the county road leading to the site. Over the years the bronze marker was stolen and replaced at least twice. It was taken down during World War II. The site was available for public visitation and local civic groups conducted occasional cleanup projects.

In February 1948, Lancaster Pollard, then Director of the Oregon Historical Society, reported in a local newspaper that a Hollywood studio was considering building a replica at the site for a movie about the Lewis and Clark Expedition. ${ }^{21}$ However, speculation about the authenticity of the site and the exact location of the fort was great enough to lead Pollard to contact the National Park Service and ask for assistance in completing an archeological survey at the site. The park service sent Region Four archeologist Louis Caywood to assist the historical society. Caywood excavated the site July $9-17,1948$. He reported that his excavations were done on the site of the Lewis and Clark encampment. His excavations uncovered firepits containing some animal bone material. He speculated that the firepits were from the Expedition's stay in the area, possibly the result of cooking fires and campfires from around the fort site used by the Expedition during the period of 
construction. No dating of the materials in the firepits was done, and therefore no conclusive dating of these firepits exists. While the excavations reported that the site was authentic, developments for a Hollywood movie never materialized.

Not much occurred at the site after Caywood's excavations. In 1953, an Oregonian editorial expressed distress at the deplorable condition of the Fort Clatsop site. It had become a dumping ground, strewn with litter, with no regular maintenance program. The Clatsop County Historical Society sponsored sporadic cleanup projects, but that was the only maintenance provided. The 1953 editorial corresponded with the establishment of the Astoria Junior Chamber of Commerce, or Jaycees, who needed a project for its group. Cleaning up the Fort Clatsop site seemed like the perfect project. During the summer of 1953 , the Jaycees improved the site, removed trash, mowed the brush and grass around the marker area, and restored the bronze tablet that had been in storage since World War II.

\section{The Lewis and Clark Sesquicentennial}

In 1954, the Oregon governor appointed a sesquicentennial commitee for planning Lewis and Clark Sesquicentennial celebrations. The Clatsop County community decided that the center of their celebrations would be the Fort Clatsop site. For the celebration, the Jaycees and the Clatsop County Historical Society joined together to build a replica of Fort Clatsop. The idea for a fort replica had been considered before, appearing in print in 1948 concerning possible movie construction and filming. The idea also arose in letters from a Portland doctor to 
Oregon congressional delegates and Department of the Interior officials, requesting national recognition for the site in $1953 .{ }^{22}$ The Jaycees and the Clatsop County Historical Society formed a joint committee to finance construction of the fort. Wilt Paulson, president of the Jaycees, named Wesley Shaner, Jr. their project manager, and the Clatsop County Historical Society assigned member Burnby Bell to the project. These two were the primary coordinators of the replica project.

From 1954 until August 21, 1955, when the replica was finished and dedicated, many local groups and people donated time, effort, and money. First, the project managers contacted a native Astorian named Rolf Klep, an artist who was living in New York City. They asked Klep to research the Expedition journals and provide a drawing of the fort. Next, they approached the Oregon Historical Society for permission to construct the replica, which was granted by the society's president, Burt Brown Barker. Barker also served on the Oregon gubernatorial committee for the Sesquicentennial celebration and made a personal donation of $\$ 100$ for work at the site. The Governor's committee also aided in celebration planning and coordination. ${ }^{23}$ Minutes from Clatsop County Historical Society meetings indicate that not all members of the Oregon Historical Society supported the project, due to the increased management needs such development at the site would require. ${ }^{24}$

After receiving approval from OHS, Wes Shaner and Wilt Paulson approached the vice president of Crown Zellerbach, Ed Stamm, about the possible donation of logs for the fort project. Stamm agreed to donate the logs and further 
volunteered to wolmanize the logs (injection of chemical preservatives into the wood), also at no cost. Paulson remembers Stamm saying that if they were going to build the thing, they needed to make it last at least fifty years. In all, Crown Zellerbach provided 408 logs approximately 40 feet long with a minimum of 7 inches in diameter and 11 inches at the base. The logs came from the Vernonia area and were removed from the forest by draft horses to prevent scarring by logging machinery. Crown Zellerbach provided transportation of the logs and wolmanization at their plant in Wauna, Oregon.

Next, the project managers approached the Finnish Brotherhood of Astoria for help with carpentry skills. The Jaycees had plenty of labor to donate, but no log-building construction experience to draw on. Through the Finnish Brotherhood, they received not only technical advice and more volunteers, but also the only hired help on the project, Olavi Hietaharju. Hietaharju was a Fin who had previous cabin building experience and was hired by the Oregon Historical Society as foreman for the replica project.

While the Jaycees were organizing materials and labor for the project, Rolf Klep completed a charcoal sketch of Fort Clatsop and sent it back to the project coordinators. The sketch was based on William Clark's fifty foot square floor plan and what little description was given in the journals. Due to the lack of documentation on the Fort Clatsop structure, Klep turned to the Expedition's previous fort building experience for possible clues in their construction techniques. Klep possibly also relied on examples of $\log$ cabins of the 1800 s to help formulate 
what the fort looked like, but more than a little speculation had to have been involved. For example, Klep's drawing includes gun ports in the outer walls of the fort. No mention of gun ports exists in the Expedition journals and it is unlikely they existed. The inward sloping roofs on the Fort Clatsop replica were probably derived from journal descriptions of Fort Mandan, the Expedition's previous winter quarters. Fort Mandan was built in a triangle with the roofs slanted toward an inner court. From Klep's drawing, John Wicks, a local architect, made working construction plans. Hietaharju followed these plans in the fort construction. The Jaycees also asked Mr. Klep for permission to sell copies of his sketch to raise money for the replica project, which he granted. The Jaycees sold prints of the sketch for $\$ 10$ each.

At the time of the replica building project, Wilt Paulson was manager of the Astoria airport, where he arranged for space in the airport hanger for prefabrication of the fort building. They planned to build the fort in the hanger, mark and number the logs, then send them out to be wolmanized. When the logs returned, they would reassemble the fort at the actual site. Through the end of 1954 and into 1955 , the volunteers worked on prefabrication of the replica. Hietaharju was there to direct the volunteers in the construction. Completed early in 1955, they disassembled the fort and sent the logs to be wolmanized. In early August 1955, the last of the logs returned from Wauna. To the Jaycees dismay, the log bands for reassembly were destroyed during the wolmanizing process. They returned the logs to the airport hanger, reassembled the fort and remarked the logs, disassembled the 
fort, and then moved the logs to the site. By the time the replica was finished, they had assembled it three times.

The Astoria Lions Club donated the materials and labor for building a cement foundation for the fort. Early in August, foundation lines were staked out and the foundation built. How they decided where to place the replica is somewhat sketchy. It is known that they used a spring to the north of the site as a reference point and compared it to distances given in the journals, assuming that the spring is the one mentioned. ${ }^{25}$ They also had to build the fort in relation to the county road, which at the time came right up to the marker site. A letter written by Thomas Vaughan ten years later states that OHS directed the Jaycees to place the replica directly next to the fort site. This may mean next to the bronze marker and flagpole, assuming that they were on the exact site. To decide the directional placement of the replica, the Jaycees considered the weather and the direction the fort's main gate would face. They reasoned that if the main gate faced the river, wind and rain would blow right into the fort grounds. While digging the foundation trenches, it is reported that volunteers found charcoal remnants or pits. Nothing was done with any of those materials. The National Park Service speculated in 1957 that they may have found remnants of Joseph B. Stevenson's charcoal operations.

After the foundation was laid, they assembled the replica. Ruth Shaner, wife of Wes Shaner, Jr., remembers that by the last month of the project her husband really had to push to get volunteers to help finish the replica. Many had 
grown tired of it. In an effort to get volunteers on Sundays, Ruth offered to teach Sunday school to the volunteers' children. This helped, but the project continued right up to the last minute. With dedication ceremonies planned for August 21, 1955, the Jaycees finished hanging the main gate that morning. A well, pump, picnic tables, and pit toilets were also completed during that month. Clatsop County graded the parking area and furnished rock for the parking area and access roads.

The August 21 ceremonies for the Fort Clatsop replica included dedication of the fort by Oregon Governor Paul Paterson; the Secretary of the Interior and former Oregon governor, Douglas McKay; Washington Governor Langley; the presidents of the Astoria Chamber of Commerce and Junior Chamber of Commerce; Burt Brown Barker and Thomas Vaughan, the president and director of the Oregon Historical Society, respectively; and local boy scouts who arrived by canoe. During the ceremonies, Burt Brown Barker accepted the replica building on behalf of the Oregon Historical Society. The day also included the naming of "Miss Sacajawea", a pancake breakfast, American Indian dances, a flower show, and a barbeque.

After the ceremonies and the Sesquicentennial celebration was over, site management problems for OHS increased. Rather than merely a marked historical site, OHS now had a fort, sanitary facilities, and picnic area to maintain. The Jaycees dropped any future plans they had for cleanup and improvements at the site. The first thing director Vaughan did was spend a weekend installing a chain link fence around the replica. OHS worked with Burnby Bell to coordinate 
maintenance at the site. During the summers of 1956 and 1957, OHS provided a small amount of money to pay an attendant for the summer. The attendant opened the fort during the day for visitation. During the summer of 1958, Michael Foster was hired to staff the site. Foster spent seven days a week greeting visitors, cleaning the pit toilets, and selling souvenirs for the Clatsop County Historical

Society, for which he received a small commission. ${ }^{26}$ A donation box was placed at the site to help raise money for maintenance. From the completion of the sesquicentennial until 1958, OHS worked towards national recognition for the site and its transfer to federal management.

\section{The Salt Works Site}

A parallel but different story occurred at the Salt Works Site in Seaside. One thing Lewis and Clark intended to achieve during their winter encampment on the Pacific Coast was the production of salt from ocean salt water. On December 28, 1805, Lewis and Clark sent "Jos. Fields, Bratten, Gibson to proceed to the Ocean at Some Convenient place form a camp and commence makeing Salt with 5 of the largest Kittles, and Willard and Wiser to assist them in carrying the Kittles to the Sea Coast". ${ }^{27}$ From December 28 until their return to Fort Clatsop on February 21,1806 , the salt works operated continuously. They established a campsite near a village containing four houses of Clatsops and Tillamooks. The men camped in tents, near the mouth of the Necanicum River and "100 paces" from the ocean. ${ }^{28}$ From the journals, it is evident that there were always at least three men at the site, 
but personnel shifted as necessary. George Gibson, William Bratton, and Joseph Fields were stationed at the site most of those two months.

While no description is given of the structure built for boiling ocean water, oral testimony about the site indicates a large pile of stones were formed into an oven or cairn shape with one open end to feed the fire. The fire was built inside this pile of stones and five kettles placed on the top. This oral testimony derives primarily from Clatsop stories passed down from Clatsops alive during the Expedition's stay and witnesses to the salt production. The captains reported in their journals on January 5, 1806 that the salt makers procured from three quarts to one gallon a day, which translates to about 40 gallons of sea water boiled a day. ${ }^{29}$ It was labor-intensive work, keeping the fire hot enough to boil the salt water and keeping up the supply of firewood. The journals indicate that the salt camp was extremely short on food most of the time and at least one hunting party was sent out from Fort Clatsop to hunt specifically for the salt camp. Lack of food, the constant labor demands, and more intense exposure to the weather than experienced by the men at the fort meant that by February, the salt makers were hit hard by illness. Gibson was so ill he had to be carried back to the fort, and Bratton was plagued by lower back pains for the rest of the stay at Fort Clatsop. The salt makers produced a total of about four bushels of salt, which they hoped would last them until they reached their caches of supplies along the Missouri River. Having the salt at Fort Clatsop benefitted the Expedition nutritionally and helped flavor elk meat that spoiled quickly in the damp climate. 
As settlement moved into the area, the salt works was still visible and a tradition of oral testimony developed as to the location of the site. The same trip of August 1899, that brought Olin D. Wheeler to Fort Clatsop for its identification brought Wheeler to Seaside to locate the salt works. Wheeler and his party of locals, including Silas B. Smith, went to the site on August 28, 1899, where he reported that stones from the salt works "cairn" were still visible. Smith, the grandson of Clatsop Chief Comowool, reported that it was the site his mother pointed out to him as the place where the expedition made salt. ${ }^{30}$ On June 8-9, 1900, when the Oregon Historical Society had Fort Clatsop identified, they also visited the salt works site. OHS brought a Clatsop Indian woman named Jennie Michel (or Tsinistum) to help identify the site. She was 86 years old at the time. In a deposition for OHS, she stated that she had often been to the site with her mother and other Clatsops who had been alive in 1806 during the Expedition's stay and was told this was the spot where they made salt. ${ }^{31}$ Her testimony was corroborated by Judge Thomas A. McBride, who had grown up on the Clatsop Plains and had been shown the site by Silas B. Smith's mother. Judge McBride's visit to the site took place after Jennie Michel's in December 1900.

Just as they had done with the site of Fort Clatsop, the historical society gained ownership of the salt works site, which was then referred to as the Salt Cairn. After the 1900 visit, OHS installed a fence around the ruins in cooperation with the site's owner. The site identified as the Salt Cairn was Lot 18, Block 1 of Cartwright Park, Seaside, and the owner, Charlotte Moffett Cartwright, deeded the 
site to OHS in 1910 as a gift to be held in "trust for the people of the State of Oregon for historical purposes only". ${ }^{32}$

In the 1920s, interest continued in the Salt Cairn site. In 1925, the Great Northern Railway Company, which Olin D. Wheeler worked for, along with the Spokane, Portland, and Seattle Railway, funded improvements at the site. Such historical tourist sites provided destinations for railroad passengers. Improvements included construction of a sidewalk and an iron fence with a brick foundation which enclosed the ruins.

Around the Sesquicentennial celebrations and the building of the Fort Clatsop replica, the Seaside Lions Club began a replica project at the Salt Cairn. They hauled in stones and built a stone and cement caim with five foundary kettles on top. Two bronze plaques were installed to describe the site and its importance. Senator Richard L. Neuberger dedicated the site during the 1955 Sesquicentennial celebrations. Ceremonies were also held at the site to celebrate the Oregon State Centennial in 1959.

The Seaside Lions Club continued to maintain the site and provided policing efforts as best they could. They sponsored cleanup projects at the site and the City of Seaside provided garbage service for one trash receptacle at the site. The volunteer efforts had limits, though, and the site was still plagued by littering and occasional vandalism, and there were no site repairs. Interpretation at the site was never improved beyond the 1950s bronze markers.

During the creation of Fort Clatsop National Memorial from 1956 to 1958, 
the salt works site was never seriously considered for inclusion. At the time, its satellite status was enough to discourage researching its authenticity and consideration for inclusion. It is possible that consideration for the inclusion of the salt works site might have endangered passage of the memorial's enabling legislation.

During the 1960s, the Smithsonian Institute sponsored archeological excavations along the northwestern coast of Oregon. These excavations included the exploration of middens located in a golf course southeast of the salt works site. These middens were believed to be the possible location of the village the salt makers camped by. If those middens were the same village as mentioned in the journals, then the location of the salt works camp would have been further south than the site owned by the historical society. No further excavations were completed. Supporters of the salt works addition to the memorial later maintained that further excavations would not reveal any evidence proving the middens to be the salt makers' neighboring village or any evidence of the salt makers' camp.

From 1959 until its inclusion in Fort Clatsop National Memorial, the site continued relatively unchanged under the management of the Seaside Lions Club. In 1968, a movement to have the site included in the memorial began with an offer from the Oregon Historical Society to donate the site to the National Park Service.

The Lewis and Clark Expedition collected valuable geographic, cultural, and natural information during their trek across the continent. Their discoveries and contact helped pave the way for American settlement in the Oregon country. 
During the settlement of Oregon in the nineteenth century and continuing into the twentieth, the sites of Fort Clatsop and the Salt Works held an attraction for the residents of Clatsop County and other Oregonians. Visitors and residents both took an interest in seeing where the historic Lewis and Clark Expedition spent the winter of 1805-1806. The settlers of Clatsop County took great pride in the fact that the Expedition wintered near their homes. For those reasons, the site was secured in the local history of the county. The public recollection of the site led to the preservation and protection from development by OHS long after remains of the original structure had disappeared.

From the earliest Spanish and English explorations of the Pacific Coast and the discovery of the Columbia River to the settlement of Astoria and its role in the development of the Pacific Northwest fur trade, the Clatsop County area is rich in history. Local civic and historic groups have been active in promoting and preserving that history. The desire to promote and celebrate local history led to the construction of the fort replica during anniversary celebrations. The dedication and persistence of individuals in the local community and in the Oregon historical community, who felt that federal recognition was the best way to properly preserve Fort Clatsop and the Salt Works, eventually led to the creation of Fort Clatsop National Memorial. 


\section{CHAPTER TWO: LEGISLATIVE PROCESS}

How did the Fort Clatsop site become a commemorative unit of the National Park Service? The creation of federal commemorative sites is a process which combines the standards for recognition set by the NPS and the advisory board with the desires of the public to commemorate a certain event or site. Standards and public desires are not always compatible. In such situations, other factors come into play. The creation of Fort Clatsop and the addition of the Salt Works is an example of the possible conflicting interests between the NPS and the public regarding historic preservation and commemoration. The process also highlights what factors can determine the outcome of such conflicts.

The movement to have the Fort Clatsop site nationally recognized goes back to at least 1905-1906 and the Lewis and Clark Expedition Centennial when the Oregon Development League of Astoria and the Oregon Historical Society sought legislation for a congressional appropriation to purchase 160 acres at the site and erect a suitable monument in commemoration of the Lewis and Clark Expedition. Senate Bill 440 was introduced in Congress in 1906 by Oregon Senator Charles W. Fulton requesting an appropriation of up to $\$ 10,000$. The bill was referred to 
committee and died there. ${ }^{1}$

The federal government did not consider the site again until 1935 when the National Park Service, in cooperation with the Oregon State Parks Board, conducted a survey of Oregon historic sites and their preservation needs under the authorization of the Historic Sites Act of 1935. In this survey, it was determined that the best future for the Fort Clatsop site would be management by the Oregon state park system. ${ }^{2}$ Two years later, at the March 1937 meeting of the Advisory Board on National Parks, Historical Sites, Buildings and Monuments, the advisory board also recommended that the site be state managed. These developments did not keep the local community from continuing efforts to obtain national recognition for the site. The Clatsop County Historical Society unsuccessfully asked Congress to recognize the site as a national monument in $1948 .^{3}$

With the decision to build a fort replica in 1953 and the attention surrounding the site throughout the Sesquicentennial, the movement for national recognition was renewed. Site management had been a problem for OHS prior to having the fort replica. The placement of picnic facilities and other improvements meant additional management needs at the site. OHS was not in a position to manage the site after the construction of the replica. The local community and civic groups who had put time, effort, and money into the replica project disagreed on what the best resolution was for the site's management. Most of the local community favored state management or the creation of a local group to handle site management. Those individuals felt the federal government had shown little 
interest in the site previously, so why turn the replica over to them? Clatsop County Historical Society member A.N. Thorndike wrote with regard to federal control that no more than state level management should be attempted so that there would be "fewer hands in our pockets or over our heads". 4 Editorials in the Oregonian and local Astoria newspapers suggested that if the state of Oregon had created a state park at the site, it would not have been necessary to turn to the federal government for its protection. Senator Richard L. Neuberger, the Oregon Senator who ultimately was responsible for drafting the enabling legislation for the memorial, wrote in 1956 that it was disturbing how much criticism he received from "people who make a fetish of opposing anything associated with the national government". 5

OHS director Thomas Vaughan had a different perspective on the matter. For the site to have any future and reach its potential as a historic site, Vaughan believed it needed to be in the hands of the federal government. The limited finances of the historical society could not provide that future. Burnby Bell and Wesley Shaner, Jr., the key individuals in the replica project, agreed with him. In 1953, a Portland doctor named Franklin B. Queen wrote to Secretary of the Interior Douglas McKay, formerly the governor of Oregon, and to Oregon Congressman Walter Norblad asking that they pursue national recognition of the site. To that same end, Thomas Vaughan contacted Oregon Senator Richard L. Neuberger.

Senator Neuberger was very interested in pursuing national recognition for Fort Clatsop and committed himself to the project. Neuberger was active in 
studying the Lewis and Clark Expedition and authored a children's book on the subject. He drafted legislation for consideration of the site as a national memorial. He enlisted the help of fellow Oregon Senator Wayne Morse and Senator Henry Dworshak of Idaho, as well as Congressman Walter Norblad. In July 1955, Senator Neuberger introduced legislation, cosponsored by Senators Morse and Dworshak, that required the Secretary of the Interior to investigate and report to Congress on the advisability of establishing Fort Clatsop as a national memorial. Prior legislation had asked for monument status. In the park service, monument sites generally contain a specific resource or are historically significant by themselves. A memorial is meant to be commemorative of a certain historic event or individual. Senator Neuberger recognized that the site should be designated more appropriately as a memorial of the Lewis and Clark Expedition than a monument. Senator Neuberger's legislation passed the Senate with no recorded objections.

When the bill reached the House floor, Congressman John Byrnes of Wisconsin questioned why the taxpayers money was being wasted on such legislation. He did not know who authored the legislation, but thought it ridiculous to pass legislation asking the Secretary of the Interior to do what he was already supposed to be doing under the 1935 Historic Sites Act. Congressman Clair Engle of California suggested that since the money and time had already been wasted in the Senate, they should just pass the bill on and suggested that maybe the author of the legislation wanted to "light a fire" under the Secretary of the Interior. Byrnes replied that it would be a costly fire. ${ }^{6}$ After registering his complaint that the bill 
was a useless and unnecessary waste of the taxpayers' money, the Congressman withdrew his objection and the legislation passed, becoming Public Law 590, 84th Congress. The president signed the bill on June 18, 1956.

Prior to P.L. 590, the Park Service had responded to public requests for national recognition by referring to the 1937 decision by the advisory board. According to NPS Director Conrad L. Wirth, in his response to Dr. Queen, the advisory board studied the site and "as a result of its studies of the history of the fort and its associations, the Board recommended that the Fort Clatsop area be preserved and developed as a State historical monument. It is our hope that the Clatsop County Historical Society, the Oregon Historical Society, and perhaps the State of Oregon will be able to carry out the recommendation of the Advisory Board". Wirth continued to say that the Park Service was unable to help financially, but would provide technical assistance in site restoration as best it could. ${ }^{7}$ Director Wirth repeated the same response in February 1954 to Congressman Walter Norblad, who inquired about the site on behalf of Dr. Queen. For park service administrators, the Fort Clatsop proposal for national recognition had been settled by the 1937 advisory board recommendation. The authenticity of the site was questionable due to the lack of actual physical remains and the alterations of the landscape due to agricultural and commercial development that had occurred over the years. Furthermore, consideration was given to the national significance of Fort Clatsop. The advisory board determined Fort Clatsop not to be of national significance and therefore not worthy of inclusion in the National Park 
System.

The Park Service was forced to reconsider the proposal. The National Park Service, Region Four, assigned regional historian John A. Hussey, as well as regional archeologist Paul J.F. Schumacher, to fulfill the requirements of Senator Neuberger's bill. Hussey researched the site and its history, and in December 1956 and April 1957 Schumacher conducted archeological excavations. Schumacher reported finding evidence of European-American settlement, which had certainly occurred and was well documented, but found no conclusive evidence of the actual fort remains. ${ }^{8}$ Schumacher found several firepits similar to those discovered by Caywood in 1948 and a concentration of nineteenth century artifacts which he determined to be the location of the Smith house constructed in the 1850 s.

On April 10, 1957, Hussey's "Suggested Historical Area Report" was completed. In it, Hussey concluded that the land owned by OHS under consideration did contain the original site of the Corps of Discovery's winter quarters known as Fort Clatsop. He based his decision on the oral testimony and written correspondence regarding the location of the site, an examination of the Lewis and Clark Expedition journals for information regarding the location, and by comparing the journal descriptions to existing topography. Hussey determined that while the site did not match all journal information given, no other place along the river came as close. This evidence combined with the record of nineteenth century visitations brought Hussey to conclude that the actual fort had been at or near the present replica. 
Hussey recommended, first, that the National Park Service and the advisory board recognize the need for a special area in the National Park Service for the commemoration of the Corps of Discovery. Secondly, he stated that the Fort Clatsop site met all of the qualifications of a national memorial. Finally, he recommended that the NPS conduct a survey of all the possible Lewis and Clark historic sites and select the most appropriate site for commemoration of the Expedition. If Fort Clatsop was found to be the most appropriate site, Hussey suggested certain minimum boundary acquisitions for establishing a memorial. If the Fort Clatsop site was not found to be the most qualified, then consideration was to be given to establishing it as a national historic site in non-federal ownership.

The advisory board approved Hussey's report by a mail vote and submitted it to Congress along with the recommendation that the site be established as a national memorial. The Secretary of the Interior submitted Hussey's report to Congress along with his recommendation to establish the memorial. On January 23, 1958, Senator Neuberger introduced Senate Bill 3087, again cosponsored by Senators Morse and Dworshak, in response to Hussey's report and the recommendations of the advisory board and the Secretary of the Interior. This legislation called for the memorial's creation and Congressman Norblad introduced similar legislation in the House. Senator Neuberger entered into the Congressional Record a letter regarding the importance of the Fort Clatsop site written by Dr. Burt Brown Barker, president of OHS during the Sesquicentennial construction. No objections were raised regarding the Fort Clatsop bill, which passed and was signed 
into law by President Dwight D. Eisenhower on May 29, 1958.

Prior to Hussey's report, the park service had continued to suggest state management of the site. John Hussey remembers negative attitudes toward the site by many in the Region Four office. ${ }^{9}$ Many NPS personnel felt Fort Clatsop was not an appropriate historic site for inclusion in the park system due to the lack of archeological evidence and the replicated fort building. Many who lived near other Lewis and Clark sites in Washington State felt that Fort Clatsop should not be given national recognition without any consideration for other Lewis and Clark sites.

Frank Turner, editor of the Longview Daily News in Longview, Washington, wrote that while Fort Clatsop was worthy of national recognition, it would be a travesty to do so without recognition of the site at Fort Columbia where the Expedition actually completed their mission by reaching the Pacific Ocean. In February 1958, Turner requested of Senator Warren G. Magnuson and Secretary of the Interior Hatfield Chilson consideration of Washington State Lewis and Clark sites. The economic benefits of a national memorial did not escape Turner and the influence of Senator Neuberger's involvement did not escape him either.

Many factors contributed favorably to national recognition. One was the relationship between and dedication of the Oregon Historical Society and Senator Neuberger to completing the necessary legislation. Senator Neuberger served on the Committee on Interior and Insular Affairs, which controlled legislation regarding the creation of new units under the National Park Service. Another 
favorable factor was Douglas McKay's position as Secretary of the Interior during the 1956 legislation for the site study. Former Oregon governor McKay had a longstanding interest in the site and served as the principal speaker at the Fort Clatsop replica dedication in August 1955.

Hussey's recommendations changed the Park Service's position regarding the status of Fort Clatsop. The NPS approved the designation of Fort Clatsop as a commemorative site, if it was determined to be the best representative of all Lewis and Clark sites. Why the advisory board and the Secretary of the Interior chose to forego a survey and make Fort Clatsop a memorial is unclear. It may have been that a survey would have taken considerable time and money and cause political maneuvering among the Lewis and Clark states for a national memorial.

The creation of Fort Clatsop National Memorial succeeded primarily because of the dedication of the Oregon and Clatsop County Historical Societies, with the support of other civic groups and individuals from the area and the State, and the dedication of Senators Neuberger and Morse and Congressman Norblad.

\section{The Salt Works Addition}

The legislation for Fort Clatsop National Memorial remained unchanged until 1978, when Congress amended the act by adding the Salt Works site, which was then known as the Salt Caim, in Seaside, Oregon, to the memorial holdings. The person primarily responsible for the amendatory legislation was Eldon G. "Frenchy" Chuinard. Chuinard was a doctor and an avid Lewis and Clark historian, 
author of Only One Man Died, a history of the medical aspects of the Expedition. He was also a member of the Oregon Governor's Lewis and Clark Trail Heritage Foundation Committee. Chuinard believed that the Salt Caim needed to be attached to the Fort Clatsop site, the two being critically linked in the Expedition's stay. The Oregon Historical Society still owned the site and it was maintained by the Seaside Lions Club.

In 1968, Thomas Vaughan wrote to Fort Clatsop Superintendent Jim Thomson suggesting the extension of the memorial to include the Salt Cairn. Superintendent Thomson wrote back to Vaughan stating, in his opinion, that the "negative aspects outweigh the positive". ${ }^{10}$ The park would need an increased budget, the site was detached from the rest of the memorial which created travel and maintenance problems, and its authenticity was questionable. He did not mention the fact that the memorial could not include the one city lot that contained the Salt Caim replica due to the acreage limitation in the park's enabling legislation. John Hussey also responded to Vaughan on September 19, 1968. He advised Vaughan of the proper channels to offer a donation to the park service, informed him that the National Survey of Historic Sites had determined the site was not of national significance, and indicated that its decision would be a significant factor to the park service in considering his proposal. ${ }^{11}$ The proposal lost momentum after this correspondence.

In January 1973, Chuinard began his campaign to have the site included in Fort Clatsop National Memorial and contacted Fort Clatsop Superintendent Paul 
Haertel. Superintendent Haertel responded by rejecting the idea based on the same factors outlined by Superintendent Thomson in 1968. Chuinard then wrote to Acting Secretary of the Interior John Kyl on August 27, 1973, asking for assistance in determining the proper procedure for OHS to donate the Salt Cairn site to the park service for inclusion in the memorial. Prior to Chuinard's letter, newly appointed Fort Clatsop Superintendent John Miele examined the site and reported to the regional office that there was considerable doubt regarding the actual site and that recognition on the National Register would be more suitable. ${ }^{12} \mathrm{He}$ also suggested that interpretation of the salt making could possibly be done on the current memorial grounds. With that information, John Kyl responded to Chuinard declining the donation and stating that interpretation of the salt making process would be done at the memorial. This prompted an emotional response from Chuinard that would set the stage for the next five years of bargaining for the Salt Cairn addition. On December 6, 1973, a memo from Superintendent Miele to the regional office documented a phone call from Chuinard who expressed his displeasure at Assistant Secretary Kyl's letter. Chuinard indicated he would settle for nothing less than the addition of the Salt Cairn to the memorial. Superintendent Miele respectfully restated the park service's position regarding the proposed addition. ${ }^{13}$ Chuinard then wrote to Oregon Senator Mark Hatfield, Oregon Congressman Wendall Wyatt, and Oregon Governor Tom McCall, enlisting their support for his proposal.

On June 20, 1974, Senators Hatfield and Bob Packwood introduced Senate 
Bill 3683 for the addition of the Salt Cairn to Fort Clatsop National Memorial, with Congressman Wyatt introducing similar legislation in the House. The Senate bill was referred to the Committee on Interior and Insular Affairs, where the legislation failed. In 1974, the nomination of the Salt Caim to the National Register was rejected because residential development surrounding the site had compromised the site's historical integrity.

The Oregon senators reintroduced their bill in the 94th Congress as Senate Bill 828. On November 7, 1975, the Office of the Secretary of the Interior recommended against Senate Bill 828. Prior to the 94th Congressional session, Congressman Wyatt's seat was won by Les AuCoin who then took up the battle in the House. In 1975, Dr. Chuinard and the Oregon Lewis and Clark Trail Heritage Foundation Committee, in cooperation with the Oregon Historical Society, wrote a proposal for the Salt Caim addition and sent it to Congressman AuCoin. This proposal was supported by the Oregon State Historic Preservation Office and the Parks and Recreation Branch of the Oregon Department of Transportation. In 1976, while the second attempt at legislation was working its way through the Senate, the second nomination for listing on the National Register was defeated. By the end of the 94th Congress, the Senate had passed the Salt Cairn legislation.

Congressman AuCoin, however, was not successful in passing the House version of the bill. The House Interior Subcommittee did not want to deal with the addition. The park service never altered its opposition to the addition and the failure of two nominations to the National Register supported their position. In a 
letter to Chuinard dated March 23, 1978, Congressman AuCoin explained that the "park service's primary opposition is based on the incompatibility of the Salt Cairn memorial and the surrounding residential area with further development which it feels will be absolutely mandatory if the memorial is to justify federal involvement. Particularly spooking the NPS is the notion of acquiring residential land and residences near the salt cairn, or worse, being forced to acquire them". ${ }^{14}$ What could change the status of the House bill? A show of support from Seaside, most importantly from neighboring residents.

Chuinard, the Lewis and Clark committee, and Thomas Vaughan became exceedingly irritated at the National Park Service through this process. The frustration prompted Vaughan to write in May 1978 that soon the park service would be questioning the validity of Crater Lake. ${ }^{15}$ With the letter from Congressman AuCoin, Chuinard rallied support from Seaside, as well as support from Oregon Governor Robert Straub, who wrote to Secretary of the Interior Andrus in April 1978. However, Governor Straub wavered in his support when he learned that the acquisition of residential properties might be necessary for interpretation of the site to NPS standards.

By May 1978, the back and forth struggle between Chuinard and the Park Service over the Salt Cairn reached a head. The park service maintained that the site's location was questionable and that the historic scene was non-existent and could not be re-created without the acquisition of at least the piece of property separating the site from the beach and ocean. Chuinard responded that the exact 
site could not be accurately determined by archeological research, that oral testimony from the turn of the century should not be discounted, and that they were not asking for immediate development of the Salt Cairn site, only that the park service accept management of the site so it had a secure future. For every concern the park service expressed, Chuinard had an answer.

The turning point came with the appointment of Congressman Phillip Burton of California as the chairman of the House Interior Subcommittee in the 95th Congress. Burton developed the tactic of the omnibus bill during a time when Congressional control over the creation of new park units increased. ${ }^{16}$ Burton pulled together many individual proposals for park units into one larger bill that would ensure enough votes for it to pass. With his position as chairman in 1978, Burton developed the National Parks and Recreation Act of 1978. This act included the Salt Cairn addition to Fort Clatsop National Memorial, as well as creating a dozen parks and increasing the acreage of a number of others. To ensure the votes of the Oregon delegation, the struggling Salt Cairn legislation was included and the bill was passed on November 10, 1978, and signed into law by President Jimmy Carter. The Oregon Lewis and Clark Trail Heritage Foundation Committee and the Oregon Historical Society planned transfer ceremonies which were held on June 23,1979 , with Senator Hatfield in attendance. The tenacity of Dr. Chuinard and his fellow supporters paid off and the park service adjusted to the addition of the Salt Cairn to Fort Clatsop National Memorial.

The enabling and amendatory legislation for Fort Clatsop National Memorial 
is typical of the legislative process for historical and commemorative sites. The 1935 Historic Sites Act delegated control and regulation of the nation's historic sites to the National Park Service, but their authority and legitimacy in controlling the selection of these sites has been challenged by the public and by Congress. In his book, Remaking America, John Bodnar states that regardless of "how hard the service attempted to keep the process orderly, political influence, local pride, and personal feeling constantly intruded into the deliberations of the NPS professionals". ${ }^{17}$ From 1935 through the 1970 s, a broad mix of historical sites were given national recognition with little regard for park service guidelines. For congressional members, historical sites provide an opportunity to give something to their constituents, as well as serve their own personal pride in the history of their district. Historical parks are generally small and require small budgets, usually relieve a local historical society, and generally don't require land condemnation. ${ }^{18}$ In the campaign for national recognition, the Fort Clatsop site had strong community support dating back to at least 1905 , the support of the state historical society, and, most importantly, the support of Senator Richard Neuberger and succeeding Oregon congressional delegations. These factors resulted in the successful establishment of Fort Clatsop National Memorial. 


\section{CHAPTER THREE: MANAGEMENT GOALS OF THE NPS AT FORT}

\section{CLATSOP}

In 1958, when Fort Clatsop National Memorial was created, the National Park Service was two years into a program called Mission 66. After World War II and into the 1950s, the National Park Service experienced an explosion of increased visitation. Most parks were unprepared for these increases and park budgets did not provide for improvements and increased accommodations. Parks also suffered deterioration of existing facilities from overuse.

In 1951, when Conrad Wirth replaced Newton Drury as Director of the National Park Service, a program of rebuilding began. Director Drury had resigned from his position following a controversial struggle with the Bureau of Reclamation over a portion of Dinosaur National Monument. ${ }^{1}$ This struggle and the preservation policies of Director Drury alienated the park service from public and congressional support, which was reflected in a lack of increased appropriations. Director Wirth began his term by rebuilding ties with Congress and advancing the needs of the National Park Service. This culminated in the development of the Mission 66 program. 
Mission 66 aimed not only to rebuild park infrastructures to accommodate increased visitation and continued preservation, but it was also aimed at organizing and strengthening the service. During the war years and the leadership of Director Drury, the service experienced decreased budgets and pressures for the exploitation of park natural resources to aid the war economy. Conflicts such as Dinosaur National Monument threatened the legitimacy of park service policy. Mission 66 was intended to meet the demands of the public and to legitimize the agency's control and authority over the nation's parks.

To meet these goals, the NPS built or improved park and administrative facilities and roads. NPS planners developed the visitor center, creating one building to accommodate visitor and administrative needs. Across the nation, one hundred fourteen visitor centers and 2,000 miles of roads were built or improved during this ten year period. ${ }^{2}$ The development of Fort Clatsop National Memorial occurred during the Mission 66 phase.

\section{Lands}

Public Law 85-435 provided for the creation of Fort Clatsop National Memorial and authorized the Secretary of the Interior to identify lands associated with Fort Clatsop, as well as portions of the overland trail from the fort to the coast, for inclusion in the memorial and to acquire those lands through purchase, donation, or other necessary measures. Establishment of the memorial would be realized when at least 100 acres were in federal ownership. The task of identifying 
and acquiring lands for the park was the responsibility of the Region Four Office (Region Four was renamed the Western Region Office in 1978) in San Francisco. Region Four received assistance from the Western Office of Design and Construction (WODC) in San Francisco, and the Columbia River Recreation Survey Branch (CRRSB), a NPS field office, in Portland, Oregon.

The lands identification process began with John Hussey's 1957 report. In that report, Hussey identified requirements for establishing a memorial at the site and suggested three possible boundaries. The boundaries he established took into account the re-creation of the historic setting, proximity of the existing county road to the site, proximity of a neighboring residence, and needed administrative buildings. Hussey's minimum boundary recommendation called for a 32 acre site that included the canoe landing and mooring sites, the spring to the north, an area to the west for administrative buildings, and space to provide a screen between the fort and the neighboring residence. The second boundary recommendation called for ninety-five acres and included the neighboring residence and property, more land to the south for re-creation of the historic setting, and room to relocate the entrance and exit road and restore the bluff below the fort building, where the existing county road cut through, to its natural state. A third recommendation included acreage along the east bank of the Lewis and Clark River, visible from the fort site, for the historic setting and to provide a buffer from modern improvements. After the submission of Hussey's report to Congress in August 1957, Senator Neuberger drafted the enabling legislation for the establishment of the park which 
would become law in May 1958. A maximum acreage limitation of 125 acres was written into the enabling legislation. The reasons for the limitation are not clear. Correspondence between the Western Regional Office and Washington, D.C. show that those involved in planning the park's development wanted to avoid a land limitation. From April 1957 to February 1958, correspondence regarding Hussey's suggested boundaries indicates that the Western Regional Office considered 100 acres the minimum acreage acceptable for establishing the memorial, leaving other recommended lands for possible future acquisition. Recommendations from the Assistant Regional Director to the NPS Director dated January 7, 1958 suggested a 100 acre minimum and stressed that if legislation was introduced in Congress for establishment of Fort Clatsop National Memorial, the service should avoid having an acreage limitation written into the bill. A letter from Region Four Director Lawrence Merriam to the Director of the National Park Service dated February 13, 1958, advised that the acreage limitation be dropped from the Fort Clatsop bill. Merriam stated "In view of our past experience with historical areas, we are aware that such arbitrary maximum limits are frequently a severe handicap in the proper administration and development of historical parks and monuments. Witness our land problems at Cabrillo, Whitman, and Fort Vancouver. In the case of Fort Clatsop, we think such a limit would be particularly unfortunate, since we would be debarred from obtaining any really significant portion of the Lewis and Clark trail to the Coast even should it be donated to the United States. In our opinion, the greater part of the suggested 125 acres will be urgently required to protect the 
immediate vicinity of the fort site itself. Therefore, we recommend that an attempt be made to eliminate this provision from the bill". ${ }^{3}$ No documentation indicates why an acreage limitation was written into the legislation. Correspondence indicates a hesitation on the part of those involved in planning the memorial to introduce anything into the legislative process that would endanger the memorial's completion. The limitation may have been necessary to ensure its success.

On August 6, 1958, John Hussey completed "The Lewis and Clark Trail from Fort Clatsop to the Clatsop Plains, Oregon", a report in which he studied the identification and preservation possibilities of a section of the overland trail from the fort site to the Clatsop Plains. The enabling legislation for the memorial intended the inclusion of portions of the overland trail to the Pacific Coast used by the Lewis and Clark Expedition. Hussey concluded that 575 acres of timberlands could be obtained to protect the historic values of the trail portion and that such action would be desirable provided that the necessary land acquisition did not adversely affect the lands acquisition process surrounding the memorial itself. The report also examined the possible inclusion to the memorial of a particular tract of forest land that belonged to the Crown Zellerbach Corporation. A news release issued from Senator Neuberger's office on June 22, 1958 reported that the Senator intended to discuss with the Crown Zellerbach Corporation the possible donation of a "segment of virgin evergreen timber stockading"4 the trail to the Clatsop Plains. The tract was a stand of old growth hemlock located approximately 0.6 mile west of the fort site and consisted of about eleven acres. Hussey recommended no 
further consideration be given to this proposal. He dismissed the possibility of such a donation because of possible land use conflicts that would arise if the tract was obtained and the lands between the memorial and the eleven-acre site continued to be owned by Crown Zellerbach. He also expressed doubts that the section of forest in question was truly old growth.

On August 19, 1958, Region Four Division of Recreation Resource Planning submitted the "Boundary Study Report for Fort Clatsop National Memorial". The report was requested by Region Four Chief of Division of Recreation Resource Planning, Ben $\mathbf{H}$. Thompson, to study boundary proposals for the park. Members of the planning team that developed the report were John Hussey, CRRSB Chief Neal Butterfield, WODC landscape architect Richard Barnett, CRRSB landscape architect Edwin L. Arnold, and CRRSB recreational planner Victor T. Ecklund. The report began by restating Hussey's first and second boundary proposals, for thirty-two and ninety-five acres respectively, to preserve the fort site and some of the historic setting. The planning team recommended two additional proposals which included the site and historic scene, relocation of the county road, the necessary visitor and administrative facilities, parking, employee housing, and utility facilities. Their first recommendation utilized 125 acres, which provided for the road relocation, visitor and parking needs, minimum residential and utility needs, and minimum protection against future incompatible developments. Their second boundary recommendation was for 418 acres, which provided for additional protection of the site and historic scene, inclusion of necessary facilities, and 
buffers against future developments. The planning team also considered Hussey's trail to the Clatsop Plains proposal. While they agreed with Hussey's recommendations for preserving a portion of the overland trail, they recommended not pursuing the trail proposal until such time as the memorial legislation would not be endangered. On August 19, 1958, Acting Regional Director Herbert Maier recommended to the NPS Director that the trail be made a separate consideration so as not to complicate the memorial objective. The trail proposal was left for future consideration. Although the enabling legislation had been signed into law with the one hundred twenty-five acre ceiling, the planning team continued to recommend plans for a larger park which exceeded that limitation.

The regional planning division, working in conjunction with the Portland field office and WODC, identified eleven tracts of land, totalling 124.97 acres, to complete the first boundary proposal in the study report. Sixteen tracts were identified that would have completed the second boundary proposal of 418 acres. The Portland field office worked with Clatsop County offices in establishing possible boundary lines. Consideration was given to existing property lines and developments, topography, the best possible relocation of the county road, necessary facilities, and historic site protection.

On March 11, 1959, Director Conrad Wirth designated the planning team's first proposal of 124.97 acres as the official boundary of the memorial and authorized the regional office to proceed with acquisition of identified tracts, making additional adjustments as necessary, as long as the 125 acres was not 
exceeded. The Secretary of the Interior approved this designation and the regional office proceeded in acquisition of the eleven tracts.

In addition to having to deal with the individual land owners, the park service had to deal with a number of separate rights attached to the properties in question. Clay and mineral rights, railway rights, diking rights, road rights, prospecting rights, and easement rights to Pacific Power and Light for power lines pertained to the various tracts identified. Most of the tracts had a combination of different rights attached to them.

Of the eleven tracts identified, five tracts totalling 21.2 acres were donated. They included: tract \#8 donated by the Oregon Historical Society, which included the fort replica; tract \#1 donated by Clatsop County; tract \#2 donated by the Clatsop County Historical Society; and tracts \#3A and 3B donated by the Crown Zellerbach Corporation. Senator Neuberger was again a major influence in the development of the memorial by suggesting and encouraging the president of Crown Zellerbach to donate land for the memorial's establishment.

The remaining six tracts, totalling 103.77 acres, were purchased from neighboring land owners. They included: tract \#6 owned by R.J. and Jean Kraft; tract \#7 owned by Kenneth and Ruth Miller which included a house; tract \#5 owned by J.K. Roberts; tract \#9 owned by Archie Riekkola; tract \#10 owned by Elmer and Barbara Miller which included a barn; and tract \#11 owned by Otto and Alice Owen. Total cost for purchasing the six tracts was $\$ 46,150 .^{5}$ In October 1962 , the Secretary of the Interior announced that the 124.97 acres of the memorial 
had been donated or purchased.

In all, nine rights (two mineral, four clay, and three railway) were obtained, all through quitclaim donations. Quitclaim donations were given by Gladding, McBean, and Co., Crown Zellerbach, and Clatsop County. Clatsop County also quitclaimed rights to the portion of the county road passing through the memorial boundaries. All rights to memorial lands are currently owned by the federal government.

One year after the final papers had been cleared for all land purchases, Alice Owen offered to sell the remainder of the Owen property to the memorial. In the creation of the memorial, the park service had purchased only a portion of the Owen property. Shortly after the purchase, Mr. Owen passed away and Mrs. Owen desired to sell the rest of their property, consisting of 79 acres. Superintendent Charles Peterson informed the regional office about the offer and inquired about the possibility of purchasing the land. The answer was negative. Purchasing the 79 acres meant not only finding the funding but also getting amendatory legislation through Congress to increase the memorial's acreage limitation.

The memorial's inability to purchase the 79 acres would later cause a public relations problem. In 1970 , R.J. Hjorten, owner of the property, inquired if any road rights-of-way were maintained by the Owens in their sale to the park service. In 1961, when the park service relocated the county road, the Owens' road was obliterated and they apparently accessed the remainder of their property through a private neighboring road. In 1975 or 1976 , Hjorten requested permission to build a 
100 -foot road from the county road to his property that would have cut through the far northwest corner of the memorial property. Superintendent Paul Haertel reviewed the proposal and referred it to the regional lands division. Upon further investigation, the service learned that Clatsop County had reserved a public use right-of-way from the old U.S. Highway 101 inward to the Hjorten property. This meant he had the ability to build a 1400 -foot road: Because he had legal road access, the service rejected his proposal.

Almost two years later, Hjorten countered by offering a land exchange. He proposed exchanging a strip of his property adjacent to the western edge of the memorial boundary for an equal amount of land from the northwest corner of the memorial property. The exchange would have allowed Hjorten to build the 100foot road he had proposed earlier without cutting through memorial lands.

Superintendent Bob Scott recommended acceptance of the proposal, but the regional office was not receptive. However, the park service never had to make a decision regarding this offer. In November 1978, Hjorten conveyed his property to Publisher's Paper Company. The eight-year wait was frustrating for Hjorten, who claimed he could not develop or sell the property without a road. Hjorten had written to Senator Mark Hatfield in 1975 requesting assistance in dealing with the park service. Senator Hatfield inquired about the matter on his behalf, questioning why an agreement had not been reached. After eight years with no resolution, Mr. Hjorten rid himself of the property, probably due to the inability to reach a compromise with the park service. 
The memorial's land holdings changed for the first time when the National Parks and Recreation Act of 1978 passed Congress and the Salt Works site in Seaside was officially added to the memorial. This legislation amended the memorial's enabling legislation by increasing the acreage limitation to 130 acres. The addition of the 100-by-100 foot city lot was donated to the park service by the Oregon Historical Society on June 23, 1979. The addition raised the total acreage of the memorial to 125.2 acres.

In 1989, Fort Clatsop was offered thirty-two acres on the east side of the Lewis and Clark River, adjacent to the memorial's eastern boundary for $\$ 32,000$. The property belonged to Cavenham Forest Industries, who acquired Crown Zellerbach assets in May 1986 and continues to own the timber property to the west of the memorial as a division of Hansen Natural Resources Company. Superintendent Frank Walker informed the regional office of the offer and inquired about the possibility of acquiring the land. Other parties were interested in acquiring the property and the issue of external threats to the memorial through the development of this property had to be addressed. Superintendent Walker favored the acquisition, but the regional office responded negatively for the same reasons the Owens' offer had been turned down in 1963. Superintendent Walker then contacted Michael Foster of the Fort Clatsop Historical Association Board. The cooperating association board agreed acquisition of the property was in the best interest of the memorial as protection from outside development that would be inconsistent with the memorial's goals. Foster contacted Cavenham Industries and 
negotiated the land purchase. The association purchased the thirty-two acres for $\$ 16,000$ and continues to hold the property until amendatory legislation raises the acreage limitation and the memorial can incorporate the property.

\section{Site Development}

In 1960, the creation of an administrative staff for the memorial began.

Charles Peterson, formerly the Assistant Superintendent at Morristown National Historical Park, became the first superintendent of the memorial on May 29, 1960. On September 30, 1960, Fort Clatsop National Memorial became an official administrative unit of the National Park System. In October 1962, the 124.97 acres identified by the planning team as the best possible acquisitions for the memorial's establishment were vested in federal ownership. The Secretary of the Interior issued a public statement declaring the memorial formally established pursuant to P.L. 85-435 (72 Stat. 153).

Beyond the proposal and successful campaign for creation of a national park unit, the National Park Service staff involved in a park's formal establishment develop a concept for that park's design and function. For Fort Clatsop, that concept was begun by John Hussey in his suggested historical area report. His idea for a memorial at the site was shaped by Mission 66 development policies and visitor use attitudes. Hussey recommended that a memorial at the Fort Clatsop site interpret the historic Lewis and Clark Expedition through the use of the fort replica and the re-creation of the historic setting. Hussey recognized the need for a visitor 
center, providing visitor facilities, interpretive exhibits, and administrative offices. In order to re-create the historic setting, the relocation of the county road would be necessary, as well as planting trees and foliage for screens between the fort replica and all modern improvements. ${ }^{6}$ It was John Hussey who first imagined the memorial as a park where the visitor could leam about the Corps of Discovery through interpretive media in a visitor center and then be able to walk to the fort replica and experience a change in environment, from the modern to a re-creation of the environment that the expedition experienced.

Site development involves the implementation of that park concept. The planning team directed to establish boundaries for the memorial, working under the acreage ceiling, selected lands around the fort site that allowed for development of the memorial. After ownership of those lands was acquired, the process of achieving John Hussey's concept of Fort Clatsop National Memorial began to develop.

From 1960 to 1965 , the period of Charles Peterson's term as superintendent, four projects formed the genesis of the memorial as an operating unit of the National Park Service. These four projects were: the relocation of the county road, the development and building of the visitor center, the remodeling of the fort replica, and the creation of a park master plan.

\section{Relocation of Fort Clatsop Loop Road}

In 1958, the county road passing the Fort Clatsop site, the Fort Clatsop 
Loop Road, cut through the ridge between the fort site and the Lewis and Clark River, past the canoe landing and mooring site. A small access road and parking area was located right next to the fort replica. If the memorial was to recreate the historic setting of 1805-1806 at all, the road would have to be moved. NPS Director Conrad Wirth agreed with this assessment when he viewed the site from the air in $1958 .^{7}$

The Region Four planning team, in deciding the memorial's boundaries, did so with consideration to the existing county road and its recommended relocation. They chose to shift the county road west, almost to the edge of the proposed western boundary. The existing road would then be demolished and the strip of land returned to its natural state. The park service also wanted control of the section of Fort Clatsop Loop Road passing through the memorial's boundaries. To obtain this, the park service asked Clatsop County to quitclaim all rights to that section of road. In return, the county would continue to maintain the road through special use agreements with the park service. The Clatsop County commissioners were at first reluctant to this arrangement and did not want to quitclaim the county's right-of-way. The commissioners were concerned with the County's status in the maintenance agreements and the quality of the reconstructed road section. ${ }^{8}$

Because a good portion of the lands surrounding the memorial were timberlands owned by timber corporations, the county road was used heavily by logging trucks. The county commissioners wanted assurances from the park service that the reconstructed road would be able to handle the weight of loaded logging 
trucks and not interfere with their use of the road. In addition, the county also was concerned that the special use permits with the park service would be revocable and about the source of funding for any future construction. On August 14, 1961, the Clatsop County Engineer approved the road design for the relocation. The Clatsop County Commissioners agreed to the quitclaim arrangement, providing that the agreement contain the statement that the county would not be responsible for the costs of any future construction. The quitclaim deed was recorded August 30, 1961.

During the summer of 1961 , the road relocation began. The construction contract was awarded to a local construction company, Grimstad and Vanderveldt, Inc. During the construction period, not only would the new section of road be completed, but all entrance and exit roads and parking areas as well. An entrance/exit road from Fort Clatsop Loop Road to a parking area and the visitor center location was constructed, as well as an entrance road to the memorial's residence \#1 (the house purchased from the Millers), a spur road to residence \#3 (employee residence to be built by the Park Service), a spur road from Fort Clatsop Loop Road to the utility structure, and parking areas at both residences, the utility structure, and visitor center parking. The visitor center parking area provided for twenty-seven cars, with three bus and trailer spaces. The original parking plan provided for only fourteen cars. Superintendent Peterson recommended the increase and tried to increase the parking area further just prior to the construction's completion. A total of 7,407 feet of road and 2,366 square yards of parking were 
constructed. $^{9}$

Since the original construction of the memorial's roads, the parking area has been upgraded three times and spur roads behind the visitor center were paved. Clatsop County continues road maintenance through special use agreements.

The contract with Grimstad and Vanderveldt, Inc. was modified during road construction to include the razing of certain existing structures to make way for the construction of new memorial buildings. The Miller barn, corral, and shed which lay in the path of the new road, and the Kraft's shed and corral which was visible from the entrance road, were to be eliminated. The ruins of the canoe landing site dock, previously owned by the Crown Zellerbach Corporation, were also to be removed.

\section{Building Construction}

Fort Clatsop's rural location required construction of all necessary visitor and administrative facilities. The Region Four planning division determined the memorial would need a visitor center, at least one employee residence, and a utility structure. In purchasing the Miller residence, the memorial would already have one, two-bedroom house available for employee housing. Funding was made available to build an additional employee housing unit. A contract was awarded in March 1962 to the McLinn Construction Company of Tacoma, Washington for the construction of the visitor center, employee residence, and utility shop. McLinn submitted the lowest bid of $\$ 103,281$. The visitor center building was designed to 
hold administrative offices for the park staff, an exhibit hall and auditorium for interpretation, a visitor information and sales counter, and other visitor facilities. The visitor center was designed by the WODC office in conjunction with the park staff. The structure was 3,300 square feet. It contained three offices, a combination mail/break room, and a small 36-seat auditorium. The structure was typical of the Mission 66 era visitor center construction. The three bedroom residence was built at the north end of the memorial. Near the employee residence, a small utility structure was built for use as a maintenance facility and storage unit.

All construction took place between June 30, 1961, and January 1963. Special use permits were obtained for utilities and lines installed. Public dedication ceremonies for the visitor center were held on August 25, 1963, which also marked an anniversary of the National Park Service.

\section{Restoration of the Fort Replica and the Historic Setting}

In considering the site of Fort Clatsop for national memorial status in 1955, an important issue for the park service was the accuracy of the replica. The use of replication and restoration in the interpretation of America's historic sites and the proper application of these mediums has been debated by park service historians since the NPS incorporation of national historic sites under the 1935 Historic Sites Act. The problems of legitimacy and accuracy in replications troubled the park service from the beginning at the George Washington and Abraham Lincoln birthplace memorials. Both sites were received by the park service with 
erroneously replicated buildings. With regards to Fort Clatsop, it was important to the park service that the goal of historical accuracy and the presentation of the Lewis and Clark Expedition not be compromised by faulty reproduction.

When national memorial status was granted to Fort Clatsop, research to improve the historical accuracy of the replica began with the 1959 "Historic Structures Report and Furnishings Plan, Part One". The report consisted of six sections: administrative data, prepared by John Hussey; historical data, prepared by historian Carl P. Russell ${ }^{10}$; architectural data, prepared by WODC architect Charles S. Pope; archeological data, prepared by Paul J.F. Schumacher; landscape data, prepared by landscape architect Harold G. Fowler; and the furnishings data, also prepared by John Hussey.

In the administrative data section, Hussey listed the report's conclusions. In the context that the replica would be used as a historic exhibit, it was determined that "the existing log shell... will require reconstruction to remove elements admittedly not now historically accurate and to add features to bring the structure into conformity with what is known concerning the original Fort Clatsop built by Lewis and Clark in 1805-06". " Hussey estimated the reconstruction would cost $\$ 17,000$ for all materials, labor, surveys, plans, and supervision. Since the 1960 fiscal year budget included $\$ 8,000$ for the memorial, Hussey requested an additional $\$ 9,000$ be allocated.

The historical data for Fort Clatsop was compiled mainly from the examination of the Expedition's journals and notes. Carl Russell examined this 
documentation for any information regarding the physical nature of the structure, the construction methods used, the resource materials available to the Expedition at the site, the tools and equipment in the Expedition's possession, and the type of furnishings constructed. Russell researched William Clark's involvement in the construction of other frontier forts, both before and after the Expedition, looking at the style of construction familiar to Clark. Russell also examined the journals and notes regarding the building of the Expedition's previous winter quarters, Fort Mandan, completing a sketch of the Fort Mandan structure from that documentation.

From all these sources, Russell gave his estimate of the materials and construction styles used in building the fort. For example, Russell concluded that the party probably did not peel the logs for the fort, that little shaping of the logs was done, and that there was no conclusive evidence of what style of corner notch was used in construction. Russell also discussed the tools used by the Expedition and how their use would have affected the construction style and look of the fort. The style of furniture was also examined and Russell included sketches of what he believed the furnishings looked like. Appendix B of the report listed tools and food stores.

Finally, Russell compared the replica to the data he had compiled and recommended several improvements for making the replica more representative of the available data. Briefly, these were:

1. Provide earth fill to hide the exposed concrete foundation of the replica. 
2. Stain the logs to replicate a natural weathered look. The wolmanization process had caused a yellowing of the replica logs.

3. Use a clay plaster mix utilizing clay deposits on site to daub between the replica logs. No daubing had been done on the replica and the Expedition journals specifically mention "chinking and daubing" in constructing the original fort.

4. Replace the cedar shake roof with hand hewn plank roofing.

5. Install wood gutters to conceal the existing gutters. Russell felt that with public use, methods should be used to keep the parade ground from turning into a quagmire.

6. Create smoke vents in ceiling of rooms with central fireplaces.

7. Build a fireplace with exterior chimney for the captains quarters.

8. Make and install hand hewn plank flooring for rooms.

9. Create central fireplace pits for rooms with central fireplaces.

10. Create half lofts for storage in captains' quarters and at least two enlisted men's rooms.

11. Make doors for all doorways.

12. Construct sentry box loosely, resembling a small outhouse without a door.

13. Install the water gate, or second gate, in the back corner of the parade ground. A wood pile for firewood supply should be kept outside this gate.

14. Replace or conceal iron hinges on main gate.

15. Cover the parade ground with fill to prevent quagmire of mud. 
16. Construct crude furnishings, bunks, tables, and chairs, and lay out examples of items the Expedition used.

In completing his recommendations, Russell gave examples of other park service reconstruction projects, such as the reconstructed army hut at Morristown National Historical Park, for comparison and construction data. ${ }^{12}$

In conclusion, Russell stated that if the park service were to build a replica of the Fort Clatsop structure from scratch, it would probably be rougher and have less concern with permanency than the existing replica. The "most glaring" errors of the replica, according to Russell, were the close fitting logs and the perfect vertical lines at the corners, which could only be corrected by completely rebuilding the replica. Due to the time and effort of the many local people and organizations in building the replica, Russell acknowledged it would be difficult to justify tearing it down and rebuilding. He believed the park service could do good interpretive work at the site if the "mark of the American backwoods craftsman" was evident. ${ }^{13}$

Architectural data consisted of the working drawings by local architect John Wicks which had been used in constructing the replica. WODC architect Charles S. Pope completed architectural drawings for the possible reconstruction projects listed by Russell in the historical data section. The construction projects detailed in Pope's drawings were covered by Russell in the historical data section.

Archeological data consisted of a review of past excavations done at the site and recommendations for further study. Paul Schumacher recommended subsurface excavation prior to completion of the landscape work. Schumacher estimated that with the use of a backhoe, the work could be completed in two to four days at a 
cost of $\$ 1,000$. Schumacher also recommended dating materials from firepits located during his 1957 excavations by a new thermoluminescent dating process.

Landscape data consisted of recommendations for the design of landscape plans at the site. Fowler determined the journals had been sufficiently researched through the site determination process. He suggested an examination of existing virgin Oregon coastal forest to determine the general appearance needed at the memorial. He recommended that WODC prepare the landscape plans at the same time that design plans for the replica restoration were completed.

Fowler gave several recommendations for those plans. He suggested that the landscaping in the vicinity of the replica and also at the outlook onto the Lewis and Clark River re-create a wilderness atmosphere. The visitor center and parking should be screened by using not only native conifer species, but also native deciduous trees such as alder. All additional plantings should be done to supplement the existing conifers and a dense forest should be avoided due to the darkness it would create. ${ }^{14}$ Screens around the outlook onto the river and Saddle Mountain would be done only to conceal physical structures. Finally, the trails to the canoe landing, spring, and eastern section of the trail to the coast should be reestablished.

In the furnishings data section, John Hussey refers back to Carl Russell's historical data report. Russell also was preparing the Preliminary Exhibit Plan for the fort replica, which provided supplementary data to his historical report. Hussey recommended following Russell's suggestions and using those guidelines as the 
replica's furnishings plan. He estimated that $\$ 5,800$ of the $\$ 17,000$ projected remodeling cost would be used for replica furnishings.

This 1959 report constituted the preliminary data for the replica construction. Part I was intended "to be a clarification of the scope of work, the coordination and resolution of the various investigations, and the definitions of guides for the work to be done in Part II". ${ }^{15}$ Part II, completed December 1962 and approved by the regional office in April 1963, outlined decisions regarding the replica restoration, responding to further investigations into the feasibility and authenticity of recommendations from Part $I$.

Part I was reviewed by the regional office, the WODC office, and the Washington, D.C. office. Superintendent Peterson made many contacts, both inside and outside the park service, for data and opinions regarding the recommendations in Part I of the Historic Structures Report. He consulted with other parks containing reconstructed log structures, including his previous work station Morristown National Historical Park, and Lewis and Clark historians. Other sources consulted regarding the original structure were the OHS depositions from 1900 and the 1957 interview with Harlan Smith.

Part II of the Historic Structures Report and Furnishings Plan was much more refined. Specific actions and purposes in remodeling the replica structure were outlined. The report was again divided into six sections: administrative, historical, architectural, archeological, landscape, and furnishings data. This report was completed by Superintendent Peterson and park historian Burnby Bell, 
incorporating review comments and additional research completed during the interim.

Administrative data presented the proposed use and provisions for operating the replica as a house museum. The replica was identified as Building \#4, category III, work code 7. The replica was to be "reconstructed, furnished, and used as a historical exhibit". In furnishing the replica, it was to look as it did the day the Expedition left. Considering theft and vandalism, the planners did not feel secure in furnishing the replica with items representative of everyday life at the fort. During the summer season, one or more seasonals would be at the fort and provide visitor interpretation. For the off season and times when no ranger was available at the fort, an audio station would be installed to provide a taped interpretive narration. Approximate hours of operation were 9 A.M. to 9 P.M. during the summer and 9 A.M. to 6 P.M. during the off season. The estimated cost for the remodeling project remained at $\$ 17,000$, including the cost of the audio station.

The historical data section, in summarizing the historical data report completed by Carl Russell and the continuing research done by the park staff, stated that the floor plan and some details of the replica conformed to the data available in the Expedition journals. "All other work done and to be done is based on conjecture and contemporary structures, and is representative of the summary beliefs of individuals who have performed research for the project". ${ }^{16}$ The report also presented information regarding the north-south directional placement of the fort. In examining the 1900 OHS depositions as well as the 1957 Smith interview 
and subsequent correspondence with Harlan Smith, the planners determined that the fort most likely was placed in an east-west direction rather than the replica's northsouth placement. The cost of reorientation of the replica was estimated at $\$ 9,000$ for construction and $\$ 1,500$ for overhead if done prior to the reconstruction, and two to three times that amount if done afterward. Overall, the planners stated that the current orientation of the replica was satisfactory from an interpretive standpoint.

The architectural data section presented modified recommendations for the replica remodeling. The recommendations made by Carl Russell in Part I were restudied and re-examined for their feasibility and necessity by park service planners. Most of the original recommendations were modified.

Recommendations for covering the concrete foundation, building half lofts in the cabin rooms, and building the fireplace and chimney in the captains' quarters remained the same. All the other recommendations were modified, most only minor changes to the design or materials suggested. The most significant changes included closing the "gun ports" located in the outside walls of the replica. Windows looking into the parade ground were to be cut and the log material taken out used to patch the gun ports. Daubing was to be done only in select spots, not all over the replica. Central fireplaces and roof vents were eliminated for all but the meat room. The sentry box would be built and used to house the visitor activated audio narration unit. All rooms and the parade ground were to be excavated with drain lines and a gravel base with shredded bark cover laid for 
proper water drainage. Gutters were to be placed only over doorways.

Reconstruction work extended over approximately five years in order to allow visitation to continue with minimal disruptions. For that reason, memorial staff established an order in which to complete the projects. The creation of parade ground windows and the closing of the gun ports received top priority, followed by the construction of the chimney for the captains' room and work to conceal the cement foundation. Construction of the water gate, the reconstruction without iron hinges of the main gate, drainage ground work, construction of the sentry box, completion of the fireplace in the captains' room, the construction of firebacks in the enlisted men's quarters, the central fireplace in the meat room, re-roofing, construction of doors, flooring, and lastly, half-lofts and shelves followed.

The park staff concluded that reorientation of the replica was not feasible and that not enough evidence supported a reorientation. With regards to the "mechanically perfect" construction noted by Carl Russell in Part I, they concluded that weathering had softened the appearance of the replica and no additional work to roughen its appearance would be necessary.

The archeological data section of Part I had suggested further excavations with a backhoe before remodeling projects began. The excavations were carried out during the summer of 1961 and the results presented in Part II. The excavations were again completed by Paul Schumacher.

During these excavations, more firepits and material from mid to late nineteenth century settlement were uncovered. No evidence of the Lewis and Clark 
Expedition was found. The report concluded that historical evidence was strong enough to substantiate the site's location and that no further excavation work needed to be done. The report also stated that excavation work would be complicated by the amount of tree roots lying underground, which would have destroyed any evidence. Since 1961, all construction work at the site has been monitored for any archeological discoveries. In 1990, a remote sensing survey of the area was completed in coordination with Oregon State University. The study revealed seven possible subsurface features, but no definitive results. ${ }^{17}$ Current speculation around the location of the original fort centers on the location of the Smith house, which is located under the trail to the canoe landing, and the memory of Harlan Smith. Smith recalled a log lying next to the Smith home as the last log of the original fort. If that $\log$ was from the original fort, than the replica is built withing 50 feet from the original fort.

The landscape data section referred to the park master plan being written by the park staff. Volume I, Chapter 5, outlined the design plans for landscaping the memorial. The area around the fort replica was targeted for replanting as well as the location of the old county road, areas between the replica and modern buildings on site, and large open field spaces to the south of the replica. Native tree and plant species were to be used.

Finally, the recommendations for furnishing the replica were outlined in the furnishings and exhibition section. Each individual room was listed with the furnishings to be constructed for each. The three enlisted men's rooms were to be 
furnished with tables and benches, a gun rack, and four bunks, each two beds high. Room \#2 was to have a tree stump with stools in place of the table and benches. This was derived from the oral testimony of settlers documenting the site who reported that a large tree stump was located in one room of the fort and used as a table. The meat storage room was to have overhead poles and wall pegs used for the hanging and drying of jerky. The orderly room would be furnished with a table, two benches, two bunks, and a gun rack. The captains room would have a large table, two chairs, two drawing boards, two single beds, and two shelves. The Charbonneau family room would be furnished with a low double pallet, a small table, and two chairs. In the parade ground, the American flag of 1805 would be flown and outside the water gate a large utility table would be placed.

The goal in furnishing the replica was to make it look as it did when the Expedition left and gave the fort to Chief Comowool. Park administration determined that the risk of theft and vandalism was too great to be able to present replica objects that would have been carried and used by the Expedition. Replica furnishings would change as the park's interpretation programs developed.

Landscaping to re-create the forest atmosphere that existed during 1805-1806 led to the implementation of a revegetation program. Tree and plant species identified by Lewis and Clark in their journals and other sources describing the plant life of the early nineteenth century were used to determine what species to plant. Landscaping around the fort replica was postponed until after reconstruction work was done. To start, tree screens were begun in 1962 around modern 
construction by transplanting young trees from other areas on the memorial ground. Revegetation would continue in various stages to fill in targeted areas from 1962 to the present.

\section{Master Plan}

The final task to complete the creation of the memorial as a functioning unit of the National Park Service was the creation of a master plan document for the memorial, which was begun in 1959 by John Hussey. When Superintendent Peterson started on June 27, 1960, he began the completion of the park's master plan. Work on this document continued from 1960 until it was approved in 1964. The purpose of Fort Clatsop National Memorial, as defined by the 1964 approved Master Plan, was "to provide opportunity at this authentic site for visitors to gain knowledge and inspiration from the story of the Lewis and Clark Expedition; and to provide awareness of the significance of this epic feat of exploration in winning the west for the United States." ${ }^{18}$

The National Park Service used six service objectives for the management of park units. They were:

I. To provide for the highest quality of use and enjoyment of the National Park System by increased millions of visitors in years to come.

II. To conserve and manage for their highest purpose the natural, historical, and recreational resources of the National Park System.

III. To develop the National Park System through inclusion of additional 
areas of scenic, scientific, historical, and recreational value to the nation.

IV. To participate actively with organizations of this and other nations in conserving, improving and renewing the total environment.

V. To communicate the cultural, inspirational and recreational significance of the American heritage as represented in the National Park System.

VI. To increase the effectiveness of the National Park Service as a "people serving" organization dedicated to park conservation, historical preservation and outdoor recreation.

Within these six service objectives, the master plan defined how the park would operate to meet those objectives:

I. To encourage visitor use and enjoyment of the park's historic, scenic, and natural resources. This was to be achieved through the maintenance of historic trails to the river, the ocean, and other historic sites; and by identifying examples of natural resources along trail routes and providing natural history interpretation at the visitor center. The park would perform historical research to provide knowledge for interpretation, preservation, and authentic reconstruction.

II. To maintain the historic setting through careful reconstruction and the use of screen plantings, proper curatorial care of the fort replica, and the separation of new developments from historic exhibits.

III. The master plan did not call for additions to the park, stating that existing boundaries were adequate for developmental needs.

IV. To cooperate with federal, state, and local agencies in resource 
conservation and encourage land use and development harmonious to the park through the appreciation of the park by the local community.

V. To interpret the Lewis and Clark story for the visitor, making sure the interpretation is appropriate for all types of visitors to the park, and to update and improve the interpretation program and facilities as needed. The fort replica and surrounding grounds would be used to make clear the conditions under which the expedition camped.

VI. To promote the training of permanent and seasonal staff as available and the use of appropriate NPS management guides and tools.

The master plan outlined possible future management programs for Fort Clatsop. These projects were divided into three categories: lands, staff, and visitor needs. The plan identified two program needs as land issues: tree planting to create screens between the fort scene and modern improvements and the development of a maintenance program to preserve the new construction. Numerous visitor needs were identified. Among them was improving the parking lot to hold an additional four buses and 18 cars, replacing the pit toilets near the picnic facilities with a modern restroom, remodeling the information and sales counter in the visitor center, enlarging the audiovisual theater to hold at least twice the present capacity, preparing and printing a historical handbook, installing better signs on Highway 101 , developing an audio interpretation station at the canoe landing, a display of American Indian artifacts related to the Expedition, installing more picnic tables, providing for park staff living on site for security, and training park staff in visitor 
safety. Staff needs consisted of utilizing training opportunities as they became available, executing regular maintenance programs, and enlarging the maintenance utility structure.

The 1964 master plan dealt primarily with visitor needs that became apparent shortly after completion of the visitor center. The need for a larger auditorium, increased visitor parking, and larger picnic facilities were the most ambitious programs identified. Originally intended to last for ten years, thirty years has elapsed between the completion of the memorial's master planning document and the final stages of a general management plan in the 1990s.

\section{Management of Fort Clatsop National Memorial}

Each unit of the National Park Service is managed at the park level by a superintendent. Due to its size, Fort Clatsop has traditionally had a small staff. During the first few years of operation, the memorial was headed by the park superintendent, who supervised the park historian, an administrative staff position, one full time ranger, one full time maintenance person, and one or two seasonal positions. Since 1970 , the seasonal and permanent staff have grown steadily. Currently, the park supports eleven full time staff positions and twelve seasonal positions.

The superintendent essentially directs a park's management. Park staff will develop programs, projects, and budget requests for various divisions of management. Management decisions and park budgets are subject to approval at 
the regional and Washington, D.C. office levels, but the essential decisions regarding the development of park programs and projects and the setting of park priorities are made by the superintendent. The superintendent must deal with all divisions of park staff. It is a position that rotates frequently between career park service management administrators and the size of the park and staff will determine greatly a superintendent's role and involvement at the various levels of park operations.

As the manager of a unit of the National Park Service, the superintendent is guided by certain legislation and service objectives. The foremost legislation guiding the park is the 1916 Organic Act which created the National Park Service as an agency under the Department of the Interior and provided for the public enjoyment of America's national parks. The 1935 Historic Sites Act also guides park management, providing for the preservation of American historic sites and antiquities under the management of the National Park Service. The Historic Sites Act also mandates the NPS provide proper interpretation and access to these sites for the public. The Antiquities Act of 1906 and the National Historic Preservation Act of 1966, as well as subsequent legislation regarding historic preservation, cultural resources, and NPS also guide management decisions. The 1969 National Environmental Protection Act and subsequent natural resource laws guide the memorial in the management of its natural resources. Specific to Fort Clatsop, the park's management must also adhere to the memorial's enabling legislation and subsequent amendatory legislation. 
Aside from federal law directing park management, established NPS service objectives guide the memorial. NPS service objectives cover administration policy in all areas of park management, from interpretation to law enforcement to natural resource management.

Within the memorial, park objectives are defined by the current staff and approved by the regional and Washington offices to meet the standards for management outlined by legislation and NPS policy. Park objectives and priorities for management are found in master plans or general management plans and in division plans, such as a natural resource management plan or an interpretive prospectus. Such management documents are written by memorial and regional staff, but change in its implementation or are rewritten as staff, superintendents, and national NPS policy and objectives change. Park management is not static, but evolves in response to changing policy and public attitudes.

At Fort Clatsop, management primarily deals with park interpretation, park infrastructure and maintenance, and natural resources. The Fort Clatsop superintendent is also involved in various community organizations, such as the Rotary Club, and often is appointed to various county, city, or state committees. The superintendent has traditionally lived at the memorial in residence \#1, the Miller house.

The following profiles of the memorial's superintendents detail their decisions in all areas of park needs. Interpretation will be discussed in more detail in the following chapter. 


\section{Charles Peterson, 1960-1965}

Charles Peterson, superintendent of the memorial from 1960 to 1965 , had the difficult task of making the memorial a functioning unit of the National Park Service. Previously the Assistant Superintendent of Morristown National Historical Park, Peterson became an integral member of the planning team when he came on board in 1960, taking over negotiations for land acquisitions, completion of management and design plans, and supervision of site construction. The master plan completed during his term outlined the purpose of the memorial and gave the park objectives in interpretation and management. Peterson hired the original staff for the memorial, which consisted of a park historian, an administrative assistant, a maintenance person, and one seasonal employee. The first park historian was Burnby Bell, who served as the Clatsop County Historical Society corresponding secretary for many years and was influential in the building of the replica in 1955 . Superintendent Peterson worked with the Western Office of Design and Construction on the design for the visitor center and offices. He supervised the development of the memorial's infrastructure, completing the evolution of the site from a locally owned historic site to a functioning unit of the National Park Service. In his 1963 annual report, Peterson reported that the transition from a construction phase to an operational phase was completed. ${ }^{19}$

During 1964, Superintendent Peterson worked on securing a suitable water supply from an outside source. Well testing on site proved inadequate for park water needs. Superintendent Peterson also began planning for expansion of 
memorial parking and the auditorium. Park visitation in the first operating year of the visitor center exceeded expectations and the year old visitor center already required improvements.

In July 1964, Peterson accepted a promotion to Fort Smith National Historic Site in Arkansas. His replacement was the superintendent of Gran Quivira National Monument in New Mexico, James M. Thomson.

\section{James M. Thomson, 1964-1969}

During his term as superintendent, Jim Thomson managed the park's needs one at a time, working from the park's master plan. Basic infrastructure necessities occupied most of his time. Often finding the park with a limited budget (in a region with such parks as Mt. Rainier, Crater Lake, Olympic, etc.), he used available funding to achieve necessary maintenance projects. ${ }^{20}$

A continuing headache was the water line to the park. The line lay at the bottom of the Lewis and Clark River and the continual presence of log rafts moving along the river caused frequent pinching and puncturing of the water line. When this occurred, all water in the visitor center, employee residences, and the utility structure would be off until the line was repaired. Repair generally took at least two days, since the repairman would have to come two hours from Portland. Construction of a reinforced water line to eliminate these pressure problems was completed in 1965.

Increased parking space was also needed at the memorial. During periods of 
heavy visitation, visitors would park in the open meadow off the side of the county road and wherever else they could find space. To help alleviate this problem, Thomson was able to get regional reserve funds to widen the current parking lot and later to create an overflow parking area. A space for 13 cars and 4 buses was cleared, graded, and graveled off the main parking and entrance road.

Upon arrival at the memorial, Thomson requested funds to add a third bedroom to the superintendent's house (the Miller house purchased during land acquisitions) in order for his family, with three sons, to comfortably live in it. In 1966, the Region Four office provided $\$ 3,000$ dollars for Thomson and told him that if he could get the work done for that amount of money, he could go ahead. Thomson contracted with a local carpenter, added a bedroom, a bathroom, expanded a storage space, and improved the electrical wiring in the house.

An important improvement to the visitor center was the installation of a ventilation system in the auditorium. The system provided much needed air circulation in the room, which was often filled to capacity with visitors.

In 1964, Charles Peterson completed a report evaluating the operations of the visitor center after its first year. Aside from limited space in the auditorium and the parking area, the most serious problem plaguing the center was the fact that out of a total 48,249 visitors, only 34,808 actually entered the visitor center. The problem lay in the visibility of the fort replica from the parking lot and the ability of the visitor to walk straight to the replica, bypassing the visitor center and its facilities. In 1966, Thomson began planting a screen of trees between the replica 
and the parking lot that would direct visitor traffic through the visitor center and then to the replica. Ross Petersen, hired as a maintenance worker, was responsible for the tree planting. He was able to provide great assistance over the years in the memorial's tree planting efforts. Petersen, who operated his own nursery, planted trees from his private nursery as well as transplanting young trees from elsewhere on the memorial grounds. By the time Thomson left in 1969, the growth of the trees and additional foliage between them such as blackberry bushes had succeeded in screening the replica from the parking lot and visitor traffic was moving through the center. ${ }^{21}$

Visitation at the memorial continued to grow. During Thomson's term, the memorial had its 100,000 th visitor. Interpretation relied heavily on the visitor activated audio station in the replica during both Peterson and Thomson's terms as superintendent. Due to their limited number, park staff were able to give tours to visiting school groups, but were not available on a daily basis for providing more detailed interpretation during general visitation. It was during Thomson's term as superintendent that the costumed demonstrations began. Park Ranger Emmet Nichols requested permission to begin blackpowder rifle demonstrations at the memorial in 1969. Nichols was knowledgeable about the weapons of the era and offered to make a buckskin outfit for demonstrations. Thomson gave his permission and they were able to acquire a blackpowder flintlock rifle. Several times daily during the summer season, Nichols demonstrated the loading and firing skills necessary to operate the weapons such as Lewis and Clark used. Off-site 
programs were developed with Fort Stevens State Park, the memorial staff presenting a film on the Expedition for vacationers camping at the state park.

With regard to law enforcement, Thomson spent time, much of it after hours, trying to curtail illegal poaching. Open fields on the outer edges of the memorial and off the sides of the county road provided attractive poaching grounds. Park staff who occupied the two residences at the memorial felt endangered by poachers shooting so near their homes. Thomson and Nichols often went on night patrols in the park vehicle or on foot, shining flashlights to warn off potential poachers. On several occasions, Thomson and Nichols would hear shots fired and would attempt to find the poachers or just get to the animal to deprive the poachers of it. Through the later efforts of the memorial's reforestation program, the open meadow areas no longer exist, but poaching continues to be a threat at the memorial.

Jim Thomson remembers managing Fort Clatsop "out of his hip pocket". ${ }^{22}$ Projects were always waiting to be done and when money became available they did what they could. In November 1969, Thomson accepted a promotion to Lake Merideth in the Texas Panhandle.

\section{Paul Haertel, 1969-1973}

Replacing Thomson as superintendent of Fort Clatsop was Paul Haertel. Haertel was previously the Paradise District Ranger at Mount Rainier National Park. Fort Clatsop was his first superintendent position and he accepted it not knowing 
anything about the memorial.

As superintendent, Haertel had five priorities: 1) to work with the Lewis and Clark Trail Heritage Foundation Committee and be able to communicate with them about the history of the Expedition; 2) to make good contacts with local community leaders and the state governor's office; 3 ) to work on developing a rehabilitation project for the visitor center; 4) to develop more living history demonstrations; and 5) to build up the maintenance staff and improve the maintenance shop.

Superintendent Haertel wanted to provided a good representation of the park service in the local community. ${ }^{23}$

Superintendent Haertel was able to fund the expansion of the maintenance shop and also to refinish the interior of residence \#3. A $16^{\prime}$ by $32^{\prime}$ work space was added to the shop. The picnic area was enlarged and landscaped and a spilt rail fence was installed around the spring site. A stone walkway was installed to the picnic area and wood chips on interpretive trails between the memorial sites were replaced. All work was done by park staff.

In regards to interpretation, Haertel hired $\mathrm{Al}$ Stonestreet to head interpretation after the transfer of Emmet Nichols. Emphasis was placed on the development of costumed demonstration programs to include more than black powder weapons demonstrations. Costumed rangers began presenting demonstrations hourly and covered the topics of weapons, tools, and clothing. Work began on furnishing the fort replica with items representative of the Expedition's supplies, specifically in the captains' quarters. The demonstrations 
were also taken to area schools for presentation. During 1972, the memorial devoted interpretation to the centennial of the park service. Nineteen seventy-two also saw the memorial's one millionth visitor.

In continuing relations with the Lewis and Clark historical community, Fort Clatsop jointly sponsored a symposium on the Expedition with the Washington and Oregon state Lewis and Clark committees. The symposium was held at the memorial and an estimated 2,600 people participated over two days. ${ }^{24}$ Two members of the Oregon Lewis and Clark Heritage Trail Foundation Committee, Robert Lange and Dr. Eldon G. Chuinard, assisted the memorial in the development of its interpretive programs.

Two public relations issues developed during Haertel's superintendency. The first was the proposal by AMAX Corporation to build an aluminum smelting plant near the memorial. The corporation was considering several sites for the plant, including Astoria. The community was divided on the issue, debating the need for jobs the plant would bring to the community against the possible pollution risks. The memorial clearly saw the plant as an external threat to the park and was opposed to a location next to the memorial. AMAX held the position that the plant would not produce any pollution that would be detrimental to the memorial.

The second issue that Haertel had to confront was the proposal for the Salt Works addition by Eldon Chuinard. Chuinard was an ardent supporter of the memorial, who provided valuable assistance in memorial interpretation programs, and Haertel worked hard to maintain a good relationship with him while at the 
same time presenting the NPS opposition to the site's inclusion.

\section{John Miele, 1973-1974}

Paul Haertel accepted the superintendent position at Lava Beds National Monument in May 1973. The new superintendent of Fort Clatsop was John Miele, who had previously been stationed in Washington, D.C., where he worked on the National Parks Centennial and on the Second World Conference on National Parks held at Yellowstone and Grand Teton National Parks. Fort Clatsop was his first superintendent position.

While at Fort Clatsop, Miele concentrated on park interpretation and the recreation of the historic scene. Miele placed emphasis in interpretation on the scientific aspects of the Expedition and the role of the local American Indian population in assisting the Expedition. Miele hired the first American Indian woman, Marsha Putman, to represent Sacagawea at the fort during the summer costumed demonstration programs. Off-site school presentations were ended and emphasis placed on high quality, on-site interpretation.

From 1973 to 1974 , Miele implemented a program to plant 1,000 trees in the open field spaces on the memorial grounds. This program was done in conjunction with the Oregon State Forestry Department which supplied the trees, ranging from 2 to 5 years old, to be transplanted at the memorial. Ross Petersen was responsible for the planting and maintenance of the young transplants, which consisted of fir, spruce, hemlock, and cedar trees. Planted areas were targeted in 
the memorial's 1964 master plan. In addition to fulfilling the master plan project, the planting also helped relieve the constant mowing and maintenance required by those open spaces. Miele saw the planting as a money and time saving effort as well as landscaping. The eventual elimination of the open meadows would also help alleviate the deer poaching.

Miele continued the memorial's opposition to the proposed AMAX Corporation aluminum plant. He also continued negotiations with Frenchy Chuinard in his bid for the addition of the Salt Works site in Seaside. Miele was appointed by Oregon Governor Tom McCall to the Lewis and Clark Heritage Trail Foundation Committee and assisted in a trip down the Columbia River identifying Lewis and Clark sites.

\section{Robert Scott, 1974-1985}

After only a year, in May 1974, Miele accepted the position of superintendent at Oregon Caves National Monument. His replacement was Robert Scott, who arrived in July 1974. Fort Clatsop was Scott's first superintendency; he previously worked as the Kings Canyon District Ranger at Sequoia-Kings Canyon National Parks. Scott would serve as superintendent of Fort Clatsop for ten years, the longest of any of the memorial's superintendents thus far.

The costumed demonstrations program continued to grow. Under Scott, the demonstrations program was defined as a "living history" program. Employment of an American Indian woman continued and an African-American man was recruited 
to portray William Clark's slave, York. Off-site school programs through the "Ranger on the Road" program were successfully performed during the first half of Scott's superintendency until budget cuts temporarily curtailed the program in 1979 . The interpretive staff continued to develop the scope and range of the demonstrations program.

General maintenance needs continued to be met, including the maintenance of all park signs, grounds, and buildings. All utility lines running to the memorial were buried to eliminate intrusion on the historic setting. Project requests for a visitor center rehabilitation continued and the park's master plan came up for review by the regional office in 1975 .

Much of Scott's time and energy went into the reforestation efforts at the memorial. Working with Ross Petersen, more than 15,000 trees were planted over ten years. Petersen and Scott established a small seed bed of tree species behind the maintenance shop for growing seedlings to transplant around the memorial as needed. Areas on both sides of the entrance road and along the west side of the county road were planted. In attempting to re-create the appearance of the 1805 1806 forest, the removal of certain tree species and filling in with more dominant species needed to be carried out. More specifically, alder, due primarily to the logging of the mid-1800s, had spread inland from the Lewis and Clark River where douglas fir, cedar, hemlock, and spruce species used to dominant. As new seedlings grew, alder was thinned. Care was given to achieve the thinning and planting without too much disturbance of the scenery for the visitor. 
In public relations, one of Scott's tasks as superintendent was the acceptance on behalf of the NPS of the Salt Works site in Seaside. Scott's feelings about the site were similar to most in the park service who had not wanted the addition because it did not meet NPS standards and criteria. After the legislation was passed and signed into law, there was nothing to do but incorporate the site and its management needs. Scott negotiated an agreement with the Seaside Lions Club to continue maintaining the site. Memorial staff began looking at the site for proper interpretive signs, markers, and landscaping. Scott also continued the memorial's opposition to the AMAX corporation, which finally chose an alternative site.

During 1982, local artist Stan Wanlass approached Superintendent Scott with a proposal to design and erect a bronze statue at the memorial for public viewing and enjoyment. Scott liked the idea and approached the Fort Clatsop Historical Association about it. The board members agreed with the project and provided funding. Wanlass created a statue titled "Arrival" which featured Lewis, Clark, a Clatsop man, and Lewis' dog, Seaman. A smaller version of the statue was cast for sale at the sales counter, as well as commemorative coins, and the funds raised used to pay for the life size version to be placed in the memorial exhibit hall. Wanlass completed the statue, working for a time in the visitor center lobby. The statue was completed and placed in the exhibit room with dedication ceremonies on September 9, 1983.

This project did incur some conflict. A member of the Pacific Northwest Region staff was against the incorporation of the statue in the memorial's 
interpretive exhibit hall. The questions raised by the staff member caused concern at the regional office, particularly over any financial obligation on the part of the NPS. The debate resulted in requesting approval from the Washington, D.C. office although the project was already underway. Approval was given by Washington and the Regional Director and the project was completed.

\section{Frank Walker, 1985-1990}

In November 1984, after ten years, Bob Scott accepted the superintendent position at Craters of the Moon National Monument in Idaho. His replacement was Frank Walker, who arrived at Fort Clatsop from Carlsbad Caverns in New Mexico. At Carlsbad, Walker served as Chief of Interpretation and Visitor Services, where he had managed a large staff and a busy schedule. Fort Clatsop was his first superintendent position.

In developing goals for the memorial, Walker recognized the need for management emphasis on infrastructure improvements. Six projects were accomplished at the memorial during Walker's superintendency. The sewer system was rehabilitated and a sewer lift station installed; parking and road improvements were completed; the trail east of the fort was made handicap accessible; shelters for the picnic tables were constructed; and the long overdue visitor center rehabilitation and the installation of temporary visitor center facilities was initiated.

The achievement of the visitor center rehabilitation was no easy task and it required working closely with the Fort Clatsop Historical Association. Walker and 
the association took steps to strengthen the association board and to organize the association's finances and management, both in response to evolving NPS guidelines concerning cooperating associations and to prepare the association for the fundraising efforts of the rehabilitation project. This began with the hiring of the first business manager in 1984 to handle the association's sales and contributions to the park. The next step was increasing the size of the association board by three members. Walker developed a close working relationship with the association.

The rehabilitation project was costly. To acquire funding, the memorial and the FCHA turned to Oregon Congressman Les AuCoin for assistance. To assist in the project, the association offered to raise $\$ 600,000$ towards the project. This fundraising was a tremendous effort on the part of the association. Their efforts also broke new ground for cooperating association contributions. Congressman AuCoin was able to appropriate 1.9 million dollars for the visitor center rehabilitation, contingent on the $\$ 600,000$ being raised by a certain date.

Many donations were received from around the community and from visitors to the memorial. However, the bulk of the funds came from grants. The association busied itself writing grant applications to every foundation they could find to ask for money. The $\$ 600,000$ was due in separate installments and the association worked to make one payment at a time, usually struggling to the last minute for each payment. Through grants from foundations like the Meyer Trust Fund, the goal was reached and in 1988 the rehabilitation project began. The visitor center would expand from 3,300 square feet to 12,000 . Lockers and showers 
for rangers doing costumed demonstrations, a separate library space, additional exhibit hall space with new exhibits, an audio visual booth, enlarged auditorium, a multipurpose room, and increased office space were all completed during the project, which would be finished in 1991.

In 1989, Walker brought Dr. James Agee from the University of Washington to the memorial for an assessment of the park's needs in continuing the reforestation program and in maintaining the forest environment. Dr. Agee completed a conceptual forest landscape plan for the memorial, outlining necessary maintenance for the continuing health of the memorial's forest.

In interpretation, Walker made policy changes that had quite an impact on the memorial's costumed demonstration programs. Under Bob Scott, interpreters in costume could only be representative of members of the Expedition itself, white males, one American Indian woman, and one African American man. That policy reflected the definition of living history utilized throughout the NPS during the 1970s. Walker shifted the memorial away from this policy and placed emphasis on hiring the best interpreters, regardless of gender or race. This shift reflected trends occurring throughout the NPS at parks utilizing living history or costumed interpretation.

Walker also reinstated the Ranger on the Road program, which brought the memorial's costumed demonstrations to Oregon schools. Working with the Fort Clatsop Historical Association, Walker arranged for $\$ 3,000$ from the association to cover the transportation and lodging costs of sending a memorial ranger on the 
road. Through this arrangement, the memorial was able to fund the program.

At the Salt Works site in Seaside, landscape improvements and the replacement of the aging sidewalk were completed. After a visitor was injured by tripping on the broken sidewalk concrete, the memorial focused on improving the look and safety of the site. A split-rail fence was installed around the area, the sidewalk repaired, and maintenance of the plant life surrounding the replica was accomplished.

Frank Walker was able to maintain a strong working relationship with the community and local organizations. Walker had monthly meetings with the heads of the Columbia River Maritime Museum, Fort Stevens State Park, and Clatsop County Heritage Museum. The meetings provided a support base for programs and projects occurring in their organizations. Out of this relationship, Walker was able to reach an agreement with the Columbia River Maritime Museum for storage of the memorial's exhibit collections during the visitor center rehabilitation. Through his involvement in the local community, Walker was able to muster strong community support for the memorial, which helped the memorial achieve the visitor center rehabilitation and other projects.

The visitor center rehabilitation planning process was complete and construction began in April 1990. In September, Frank Walker accepted the assignment as Superintendent of Nez Perce National Historical Park in Idaho. 


\section{Cynthia Orlando, 1990-Present}

Walker's replacement and the memorial's present superintendent is Cynthia Orlando, formerly the Project Manager of Ebey's Landing National Historical Reserve on Whidbey Island in Washington state. She is the first woman to hold this position at the memorial.

Arriving in October 1990, Orlando oversaw the construction of the visitor center rehabilitation project. Her first priority was the accomplishment of planned construction and the planning of dedication ceremonies in August 1991. The completion of construction, moving into and back out of temporary facilities, the assembly and installation of new exhibits, and the final touches of the project consumed the first year of Orlando's superintendency.

After the completion of the rehabilitation project, Superintendent Orlando concentrated on mobilizing the memorial against increasing external threats and adjacent land use issues. Development trends and changing land use patterns threaten to impact the memorial's resources. The potential for threatening development was noted in the memorial's 1958 suggested historical area report and boundary recommendations. In order to direct the memorial against developing external threats, Orlando campaigned to the Regional Director, Pacific Northwest Region, for a new general management plan to replace the thirty-year old Master Plan written by Superintendent Peterson.

Superintendent Orlando convinced the Regional Director that the memorial could not afford to wait for a new management plan. A planning team, consisting 
of regional and park staff, was given approval to produce a new management plan at the park and regional level. The plan received funding in 1992.

Four alternative action proposals have been developed by the planning team. The preferred action proposal contains management goals that would expand the park to include a commemorative trail to the Clatsop Plains and the coast, following as closely as feasible the route used by the Expedition. This goal is based on the memorial's enabling legislation, which states that the memorial would include portions of the Expedition's overland trail to the coast. The plan also prepares the park for the incorporation of the 32 acres owned by the Fort Clatsop Historical Association.

Aside from land expansion issues, the proposed plan establishes management goals for a new natural resource management plan, needed staff increases and staff housing, upgrading the maintenance facility, possible improvements for the Salt Works site, goals for the memorial's library, and goals for improving collections management. The expansion proposal has met with mixed and strong emotions in the local community. The plan is currently under final revisions and will face final approval by the NPS director. Amendatory legislation will be necessary for lifting the acreage ceiling.

Superintendent Orlando has increased the park staff to include a law enforcement position, a resource management position, and a part-time collections and librarian position. She has implemented a program which she calls "professionalizing" the memorial staff. Traditionally, the park's small staff took on 
the responsibility of all areas of park management, regardless of the division in which an employee worked. For example, for years the interpretation staff dealt with cultural resource management issues, the library, and collections in addition to the interpretive programs. Superintendent Orlando has sought to create a working situation in which each division accomplishes tasks that directly relates to the goals of that division.

Over half of the Fort Clatsop superintendents were serving as first-time superintendents at the memorial. Management emphasis has traditionally centered around interpretation, regular maintenance, and visitor access. The park has traditionally had no serious law enforcement problems and no serious cultural resource issues. The park's natural resource program has matured from its landscaping, revegetation program and interpretive concepts. Over the years, the memorial's staff has expanded its interpretation of the Lewis and Clark Expedition through costumed demonstrations and the furnishings of the fort replica, expanded its involvement in the Lewis and Clark historical community and the development of a research library for use by the public and scholars, and in the creation of its own forest. The memorial's staff has, for thirty-five years, endeavored to present the story of the Lewis and Clark Expedition as accurately as possible, while at the same time meeting the day to day management needs of a public memorial.

\section{The Fort Clatsop Historical Association}

The Fort Clatsop Historical Association (FCHA), established November 29, 
1963, has been an integral part of management at Fort Clatsop National Memorial. Funds from the association's sales have allowed programming and development to take place that may not have otherwise occurred. This funding allows the park staff not only to maintain programs that may have otherwise been curtailed due to budget or staffing restraints, but to plan additional programs or projects beyond the memorial's regular budget.

In 1960, the Northwest Historical Association (NHA) became the cooperating association for Fort Clatsop. This association was started for Fort Vancouver National Historic Site in 1953 and expanded to include the newly authorized Fort Clatsop. From 1960 to 1963, NHA handled sales at Fort Clatsop and oversaw the completion of the sales counter during the visitor center construction. NHA selected materials for sale at the new counter, including postcards and books. After the completion of site development at the memorial, Superintendent Peterson and park historian Burnby Bell helped organize and establish the Fort Clatsop association and ended the agreement with NHA. When this break occurred, Fort Clatsop sales averaged $75 \%$ of the Northwest Historical Association's sales. ${ }^{25}$

When the association began, it consisted of a board of directors comprised of three or four community supporters of the memorial. The memorial's chief ranger and superintendent were responsible for the ordering and sales of materials at the association counter in the visitor center. All proceeds from book and gift sales funded park interpretation. As the park's costumed demonstrations developed, the 
support of the association went to buying demonstration materials such as tanned hides for costumes, blackpowder weapons and supplies, and other items for use in the replica.

In 1974 , the association was struggling to remain financially solvent and took steps to resolve the situation. The association borrowed $\$ 1,000$ dollars, initially from Chief Ranger Al Stonestreet, in order to make the sales counter more viable. FCHA then borrowed \$1,000 from the Crater Lake Historical Association, to repay Stonestreet. By September, FCHA had repaid the loan to the Crater Lake Association. ${ }^{26}$ The association board also voted to increase in size by three members, which increased their number to six.

Also in 1974, the Pacific Northwest Regional office created the Northwest Interpretive Association, which was a joint association for Northwest parks. FCHA voted not to join this association. Because FCHA stayed an independent organization, funds raised by the sales counter stay within the association and assist only Fort Clatsop. Under the Northwest Interpretive Association, all money would belong to that organization and funds distributed to all member parks evenly. As an example, the assistance Fort Vancouver N.H.S. receives from NIA is about $10 \%$ of the sales generated at the site. ${ }^{27}$

As NPS guidelines for cooperating associations have developed, so has FCHA. In 1984, the association hired its first business manager. The National Park Service wanted to separate the association sales from the memorial staff and memorial budgets. By hiring a manager and a sales person to handle the ordering 
of supplies and selling of books, the park staff was separated from managing the association's sales. To give further strength to the association, the board of directors was increased to seven members. The board currently holds quarterly meetings to discuss association business. Annual reports of the association's budget and activities in the memorial are completed and presented to the Park Service's Washington, D.C. office.

The Fort Clatsop association has branched out over time in its support of the memorial. Some specific projects have been sponsored directly by the association. In 1984, the association funded the "Arrival" statue project. During the mid-1980s, the association helped fund the "Ranger on the Road" program, which sends park rangers out into Oregon's schools. The association has always supported the park's library collection, giving two copies of every book carried at the sales counter to the park. ${ }^{28}$ These books are used by the park staff for historical research to document the costumed demonstrations and help build the memorial's library. FCHA also gives reference books to new seasonals prior to their arrival. Recently, the association purchased the Robert Lange collection for the library, which tripled the size of the park collection. ${ }^{29}$ FCHA has purchased several other rare books for the memorial collection, including a rare Reuben Gold Thwaites volume. FCHA has purchased an additional thirty-two acres of land north of the memorial boundary for donation and protection against incompatible development near the memorial. FCHAs biggest project to date has been fundraising for the visitor center rehabilitation project and the association has gone on record supporting the 
boundary expansion and new GMP.

In 1991, the association received the Take Pride in America award from Secretary of the Interior Manuel Lujan, Jr. for its tremendous support of the memorial. FCHA is a well respected organization and serves as a model for other non-profit cooperating associations. 


\section{CHAPTER FOUR: INTERPRETATION}

Each unit in the National Park Service, whether natural or historical, is set aside for the public, and it is the job of park personnel to provide protection for the site and present the site's attributes to the public. With historical sites, the National Park Service has traditionally sought to interpret them not only for educating the public about a certain aspect of their history, but also to inspire them. ${ }^{1}$ Presentation, of either a natural setting or a historical event, is referred to as interpretation. Interpretation is "an educational activity which aims to reveal meanings and relationships through the use of original objects, by firsthand experience, and by illustrative media, rather than simply to communicate factual information". ${ }^{2}$

Over the last thirty-five years, the staff at Fort Clatsop has developed a nationally recognized interpretive program, designed to present to the public the story of the Lewis and Clark Expedition and its stay at Fort Clatsop during the winter of 1805-1806. The 1958 suggested historical area report described a potential memorial where the site of the replicated fort structure, in combination with the restoration of the historically documented coastal forest environment of 
1805-1806, could offer the visitor a physical setting in which to imagine the Expedition party. Since the opening of the visitor center in 1963, the memorial's interpretation has evolved into a comprehensive presentation of the Expedition, its encounters and effects, at the turn of the 19 th century.

The memorial began telling the story of the Expedition through exhibits and other media utilized at the visitor center and the fort replica. From 1963 to the present, the memorial has broadened the scope of its interpretation through the development of costumed demonstration programs, held throughout the spring and summer and on special occasions; increased seasonal staffing; utilization of the memorial's growing reference library collection; an expanded collection of educational films and videos; expanded and improved exhibit displays; temporary displays, including artifacts from the Lewis and Clark Expedition on loan from other institutions; the filming of costumed demonstrations on laser disc format; and the development of a variety of educational school programs, held both on and off site. The evolution of the memorial's interpretive programs has been influenced by changes in memorial superintendents and staff, changes in memorial budgets, and changes in the attitudes of park visitors. Interpretation has not been static, but adapted to meet current trends in NPS interpretive management and current social attitudes.

\section{Interpretation, 1955-1963}

After the replica was finished and the Sesquicentennial over, OHS installed 
a chain link fence around the structure for security. OHS could not afford to hire anyone to be at the site year-round for its protection and interpretation and the society was already in the midst of trying to get Fort Clatsop transferred into federal ownership. For those reasons, OHS interpretation was limited. Burnby Bell, secretary of the Clatsop County Historical Society, handled all replica business for OHS. During the summers of 1956-1958, while the outcome of the legislative movement was pending, the society was able to hire someone to open the site during the day and be on-site for protection and maintenance. This person was responsible for opening the replica, maintaining the pit toilets, answering questions for visitors, handling a donation box, and selling small, miscellaneous souvenirs for the Clatsop County Historical Society.

From 1959 until 1963, while memorial staff was absorbed in the various developments necessary to create a functioning unit of the NPS, actual interpretation remained limited. Planning for the memorial's interpretive programs began with John Hussey's concept for the memorial. Development of the memorial's visitor center exhibit and the rehabilitation of the fort replica provided the basis for memorial interpretation. Planning also included researching and acquiring interpretive materials such as films, books for the memorial's library, and materials for the visitor center exhibit. The staff consisted of two employees until 1962, and in 1963 expanded to four employees with one seasonal. For the first years under NPS management, the small staff was consumed with planning duties and construction. 
A draft interpretive prospectus was completed by park historian Burnby Bell in 1961. In the prospectus, Bell stated that three methods would be used to present the story of the Lewis and Clark Expedition to the public. These were: visitor center exhibits, the reconstructed and furnished replica, and the area itself, which would have self-guiding trails and interpretive signs. Bell outlined twelve possible exhibit cases for the visitor center. Bell also called for a display of dugout canoes at the canoe landing site, with interpretive signs. While most of the ideas in the 1961 draft prospectus for the visitor center were used, the master plan and the historic structures report determined that the replica would be furnished only with the crude furnishings left behind by the Expedition. The display of dugout canoes at the landing site and the placement of wayside exhibit signs were not realized until after 1970.

\section{Interpretation, 1963-1970}

When the memorial visitor center was completed and opened to the public in 1963 , interpretation was structured to educate the visitor about the Lewis and Clark Expedition and its contributions to the development of the nation. During the summer, one or two seasonals were hired to be at the replica to answer visitors' questions about the replica and the Expedition. Because the staff was small, visitor activated audio messages were installed to provide the visitor with a short narrative about the fort and the Expedition's stay there when no park employee was available. All the staff, including the superintendent, spent time at the front desk greeting 
visitors, selling souvenirs from the FCHA sales counter, answering questions, tallying the number of visitors, and handing out park brochures. Visitation exceeded the numbers expected. School groups visited the memorial on field trips on a regular basis, the numbers doubling from 1963 to 1964 alone. ${ }^{3}$

The visitor center exhibit was designed to treat the entire expedition, from Jefferson's instructions to the expedition's end and consequences. The centerpiece of the exhibit was a wall map, displaying the Expedition's route to and from St. Louis. Important points along the Expedition route and points of decision making, the goals of the Expedition and the scientific and geographical information collected along the way, as well as supplies and equipment were marked along the map. During the development of the visitor center, the memorial received the donation of a Northwest Coast style canoe for display as the centerpiece for presenting the American Indian people with whom the Expedition spent the winter. Other areas of emphasis included a diorama depicting the beached whale at Ecola and a picture depicting the saltmakers camp at Seaside. While park staff had input into planning the exhibit, the actual exhibit was designed and constructed by NPS exhibit designers at the Western Museum Laboratory in San Francisco, California..

The memorial purchased a few films about the Expedition from companies like Encyclopedia Britannica. These films were used at the visitor center and also taken to off-site locations, such as Fort Stevens, and shown as part of outreach programs. The memorial established a successful film loan program, which is a major portion of its educational outreach programs. The original slide program was 
created by the NPS and consisted of pictures from along the Expedition route, with narration provided by park staff showing the program.

During this time period, remodeling projects at the replica continued.

According to the "Historic Structures Report and Furnishings Plan", the replica was to look as though the Expedition members just left, supplying only the idea of their shelter and their furnishings. In 1968, the memorial's revegetation began with the planting of trees to screen the replica from the parking lot. The seclusion of the replica from the memorial's modern buildings was desirable to create an atmosphere similar to that experienced by the Expedition members.

During the 1960s, living history programs and blackpowder weapons demonstrations gained popularity throughout the National Park Service, especially in the Eastern historical sites and battlefields of the American Revolution and Civil War. Living history programs were stimulated through the concept of the living farm and NPS Director George Hartzog encouraged the development of such programs. In 1968, 41 areas reported living history programs and by 1974 the number was $114 .^{4}$ In 1968, Park Ranger Emmet Nichols began blackpowder rifle demonstrations at Fort Clatsop. This demonstration of the weapons and skills of the Expedition would become the key element of the costumed demonstration programs.

\section{Development of Interpretive Programs, 1970 to Present}

In 1970, Superintendent Paul Haertel and chief ranger Al Stonestreet placed 
emphasis on the costumed demonstrations. This included obtaining funding for more seasonal rangers to present these programs. Memorial staff researched other topics for presentation. Seasonals were allowed to research aspects of the Expedition of interest to them and to develop their own programs. They were to develop talks that were thoroughly researched and presented in appropriate format for park visitors. The growing library collection at the memorial, stocked mostly through the donation of books by FCHA, and trips to conferences and workshops about the Expedition or about 1805-1806 era life and skills, provided a knowledge base for these programs. Members of the Lewis and Clark historical community, especially Robert Lange, Eldon G. Chuinard, and Irving Anderson, also provided technical assistance to the memorial staff in accurately developing these programs. The theme of the costumed demonstrations centered around the presentation of life at Fort Clatsop during the winter of 1805-1806 and the skills employed by the Expedition to stay alive.

The journals of the Expedition indicate the types of events that occurred during their days on the Pacific Coast, as well as what types of general activities they were engaged in. Most of the material for the interpretive programs is based on the daily activities of the Expedition. Development of the programs is based on learning and researching the basic skills of frontier life, such as flint and steel fire starting, weapons skills, hide tanning, and sewing skills, among others. The basic demonstrations developed between 1970 and 1980 continue to be the backbone of the demonstration programs today. 
The principal occupation for most of the Expedition members was hunting. Almost every day during their three and a half month stay, at least three to ten members were hunting. Often they would be gone for a few days, if not several on a couple of occasions, due to the distances the hunters would have to travel to find game. At the fort, other activities were going on. According to the captains' journal entries of January 1,1806 , at least one sergeant and three privates were on guard duty at all times. Guard duties included tending the meat house fires and supplying firewood for the cabins, announcing approaching visitors, and regularly checking the status of the canoes at the landing site. ${ }^{5}$ On January 13, 1806, Lewis writes "this evening we exhausted the last of our candles, but fortunately had taken the precaution to bring with us moulds and wick, by means of which and some Elk's tallow in our possession we do not yet consider ourselves destitute of this necessary article". ${ }^{6}$ On January 9,1806 , both Lewis and Clark wrote that "Our men are now very much engaged in dressing Elk and Deer skins for mockersons and cloathing". ${ }^{7}$ On January 20,1806 , while discussing the depletion of their food stores and the lack of worry amongst them about it, Lewis states "our skill as hunters afford us some consolation, for if there is any game of any description in our neighbourhood we can track it up and kill it. most of the party have become very expert with the rifle". ${ }^{8}$ These entries are the basis for the most common activities demonstrated by memorial interpreters.

The black powder rifle demonstration generally occurs three to four times daily during the summer season. Through the demonstration of the function and 
loading of a Kentucky longrifle and a Harpers Ferry rifle, the visitor learns the skills needed by the Expedition just to feed themselves. Due to the damp climate, the visitor also learns how tricky those weapons are. Interpreters have days when a dozen attempts are necessary before getting the rifle to fire. Interpreters also inform the visitor about confrontations with grizzly bears that the Expedition faced on the way to and from the Pacific Coast, including the time Lewis found himself alone with a bear and an unloaded rifle. The visitor develops an appreciation of the effort expended by the Expedition in obtaining food and protecting themselves with these weapons.

The constant rain and exposure to the ocean weather rotted most of the Expedition's hide based tents, covers, and clothing by the time they finished building Fort Clatsop. While at Fort Clatsop, it was necessary for the Expedition to replace these items and make new clothing. Making clothing and moccasins from deer and elk hides is demonstrated by park staff. In the early 1970 s, Al Stonestreet developed basic sewing patterns for shirts, pants, and moccasins and seasonal rangers were required to make their own outfits for use at the fort. Memorial interpreters work on sewing clothing at the replica as visitors filter through, making themselves available to answer questions while demonstrating a skill employed by the Expedition. Visitors are also invited to try on the clothing as it becomes more complete.

Candle rendering is another common demonstration and also provides a functional task for the park staff. Replica nineteenth century molds are used to 
fashion candles from animal tallow, which is boiled down. These candles are then used by park staff to light the fort.

Processing of game animals is also demonstrated. This includes hide tanning and meat jerking or smoking. These demonstrations are usually subject to available funding and supplies. For sewing purposes, most hides are purchased from a supply company pretanned and ready for use. Occasionally, deceased animals are donated to the memorial by the Oregon State Police game division or hides will be donated by local hunters who have no use for them. The Expedition members practiced brain tanning for their hides, where the brain matter of the animal is smeared around the hide for loosening hair and softening the skin. After a brain mush is applied, the hides are scraped. Brain tanning is occasionally demonstrated at the fort, sometimes using beef brains purchased from local butchers when the game animals' brains are not available.

The meat jerking and smoking has been demonstrated with elk, deer, and salmon. Samples for the visitors are not allowed due to park liability. However, displays of hanging meat are shown in the meat room whenever practical. The demonstration of meat preservation methods provides an opportunity for the park staff to talk more in depth about the Expedition's diet. While elk jerky was their main staple, they also dined on various other meat and plant items and occasional treats such as whaleblubber and candlefish.

Other demonstrations are based on activities not explicitly written in the journals or are activities that took place at other points along the Expedition's route. 
Park staff also develop educational talks on topics that do not require hands-on objects or specific demonstrations.

Pierre Cruzatte, a French-Canadian member of the Expedition, was a fiddle player and on special days would play his fiddle while other members of the Expedition danced and sang along. No mention is specifically made of music and merriment in the Expedition journals during their stay at Fort Clatsop, but they did spend Christmas and New Year's Day of 1806 there. There is no evidence that they did not engage in this pastime while at Fort Clatsop. Indeed, their moods being mostly low from the weather and illness, they probably needed the entertainment. Therefore, the memorial has developed a very popular music and dance program. Since 1979 , the memorial has employed at least one seasonal interpreter who plays the fiddle for this program. Research has gone into learning the folk songs and jigs of 1805 America and French-Canada with which frontier members like Cruzatte would have been familiar. This demonstration invites audience participation and the aspect of entertainment through music and dance is an activity that the average park visitor can easily relate to, unlike hunting and brain tanning.

The Expedition relied heavily on canoes while on the Columbia River, and they greatly admired the canoes of the Chinookan populations. Along the Clearwater River in Idaho, the Expedition carved five canoes for themselves, employing methods of carving and burning they had observed from American Indian construction. ${ }^{9}$ Between 1970 and 1984, two logs for canoe carving demonstration were obtained. Seasonal rangers, using adzes, axes, and fire, carved 
canoes out of these logs. Canoe carving demonstrations have been time consuming, using three seasons to complete one canoe. When completed, the staff places the boat in the Lewis and Clark River, testing their workmanship.

Other examples of interpretive talks and demonstrations include melting and molding lead bullets, the medical aspects of the Expedition, and guided walks through the memorial examining the memorial's botany while learning about Lewis' collection of information about the local environment.

In hiring for the seasonal programs, the memorial has been able to employ interpreters who already possess experience in frontier era interpretation and skills. By allowing seasonals to present to the public aspects of the Expedition which interest them, seasonals often develop better programs due to their personal enthusiasm. For example, some seasonals are not comfortable working in game processing techniques, but are able to put together excellent botany walks. Allowing seasonals to rotate between presenting costumed demonstration programs and covering the front desk at the visitor center prevents monotony for the interpreters.

A new interpretive prospectus was completed for the memorial in 1975. The prospectus evaluated the memorial's interpretation program, suggested improvements and set guidelines for the future. The prospectus listed areas which needed improvements, in both the exhibit and replica grounds. It was determined that the slide show was boring, too long, and did not provide information any different than the film and exhibit wall. The prospectus reiterated that the 
auditorium was inadequate for heavy visitation. The landscaping around the fort replica needed to be enhanced to foster the integrity of the historic setting. Leaving the visitor center, the visitor could see the replica and walked to it on a trail that was partially covered with blacktop. More interpretive signs were needed around the replica grounds.

The prospectus outlined the interpretive goals of the memorial's program: to acquaint visitors with the story of the Expedition and its significance; to help visitors gain an insight into the daily life at Fort Clatsop; to impart to the visitor an appreciation of the role of Native Americans in the success of the Expedition; and to dramatize the courage, fortitude, and problem-solving abilities displayed by members of the Expedition so that visitors may be inspired by the explorers' achievements and bring forth these same qualities to meet the challenges of today. ${ }^{10}$

To help meet these goals and alleviate problems, the prospectus presented five recommendations to improve memorial interpretation. These were: develop a new audio/visual slide program; make small revisions to the museum exhibit (refining the wall map to include the geopolitical implications of the Expedition and rewording American Indian exhibits to avoid stereotyping); screen the trail to the fort with native vegetation; design wayside exhibit signs at the fort and canoe landing; and develop an environmental study area to hold school classes. The recommendations were implemented over time as funding was available.

Since 1970 and the development of the memorial's costumed demonstration programs, the fort replica has become an interpretive tool, the backdrop of the 
demonstration programs. In 1973, efforts to furnish the rooms of the fort beyond its crude furnishings began. The replica has been furnished with furs, hides, blankets, tools, candle molds, writing utensils, replica journals, cooking utensils, weapon supplies and cleaning materials, military uniforms, hats, flint and steel, lamps, and other items used by the Expedition members. The memorial currently has over 800 replica items which are used to foster a hands-on experience for the visitor. For example, in the captains' quarters, blank journals and writing utensils, maps, a plant press and samples of plant materials collected in the area by Lewis, and samples of Indian grass hats and mats are displayed. The visitors can touch furs, make sparks with the flint and steel, or try their hand at the writing utensils. During the winter, a small number of basic items, blankets and hides for example, remain in the rooms at the fort.

During the first fifteen years of the memorial's demonstration programs, emphasis was placed on the demonstrations as "living history". In classifying the programs as such, only representatives of members of the Expedition were utilized in costume at the fort replica. Aside from Euro-American men, the persons of York and Sacagawea could also be represented. The memorial was active in trying to hire an African-American man and an American Indian woman to represent these two Expedition members in the memorial's programs. Over the years, a few American Indian women and two African-American men have represented these figures.

The representation of York and Sacagawea was not always successful, for a 
couple of reasons. First, it was difficult to find people to hire as seasonals.

Second, the rangers representing these two individuals had to deal with prejudice present in the general public. Women representing Sacagawea faced becoming a novelty, the stereotyped "squaw", and experienced a lack of authority as park rangers. ${ }^{11}$

The portrayal of these two individuals as functioning members of the Expedition raises difficult historical issues regarding their relationships to the rest of the Expedition. In reality, Expedition journals state very little of substantive value regarding them. There can also be a tendency to project current attitudes toward race and gender onto the past. In the current era of multicultural history, the persons of York and Sacagawea can be used to fit what today's society is looking for in its history. Sacagawea, long before multicultural history, was used as a vehicle for promoting women's issues. Interpretation at the memorial has used these individuals to fulfill current concerns about what information is shown in history.

With a change in superintendents in 1985 , interpretive policy shifted regarding the demonstration programs. The shift reflected a trend found throughout the NPS costumed interpretation during the mid-1980s. Emphasis shifted from classification as "living history" to "costumed demonstrations". This emphasis created less restrictive hiring practices with regards to costumed interpreters. Superintendent Walker emphasized hiring the best possible interpreters, regardless of their race or gender. ${ }^{12}$ With less restrictive hiring policies, women interpreters 
were given the choice of wearing men's costumes as opposed to the women's buckskin dress. For example, one woman seasonal requested wearing the men's costume for her demonstration of carpentry skills, which the dress prohibited her from doing. ${ }^{13}$

NPS Directive Six (NPS-6), which covers interpretation standards and definitions for all NPS units, lists current definitions of living history and costumed demonstrations. These definitions have come about through programs like the one at Fort Clatsop. Costumed demonstrations are defined as "demonstrations, animations, etc., conducted by interpreters in period dress but not utilizing first person role playing (i.e., third person presentations)". Living history is defined as demonstrations conducted by "interpreters in period clothing who are portraying a specific historical role (i.e., first person role playing). For these activities, accuracy includes not only the knowledge base, the reproduced clothing and objects involved but also physical characteristics clearly identifiable after costuming, makeup, etc". NPS-6 goes on to state that care must be given in planning for living history programs that first person presentation does not result in unintentional discrimination.

By these definitions, which are current and a result of the development of such programs, the memorial has always been doing costumed demonstrations. Only occasionally have interpreters at the memorial done first person presentations. In such cases, interpretive staff have been careful in knowing the abilities of the person involved in the presentation. First person presentations appeared to receive 
negative visitor response. ${ }^{14}$

First person presentation requires the visitor to believe an interpreter is someone from another time and place. If the visitor is asked to believe something and they don't, two things may happen. One, the visitor will lose interest in the program and will not remember it fondly, and two, the historical information being presented will be lost. First person presentation is less interactive and requires acting. Third person is a better learning vehicle, allowing open interaction with the audience with no pretense about who the interpreter is. An interpreter with a well prepared and well delivered talk is often more effective than an interpreter acting a part.

Visitors recognize that white women were not members of the Expedition party. The issue of race and gender in costume interpretation is a debate that extends to all parks presenting such programs and draws strong opinions from members of the NPS at park, regional, and national levels. Some maintain that interpretation should continue to maintain historical accuracy with regard to race or gender, even when presenting third person presentations. They consider women in men's period clothing to be historically inaccurate.

The women who were the first memorial rangers to present demonstration in costume had mixed success. Some experienced a loss of authority with some visitors that did not occur when they wore an NPS uniform. ${ }^{15}$ Women interpreters currently working at the fort do not seem to experience this problem and only rarely experience problems. Incidents fostered by the gender of the interpreter 
therefore seem to have declined over the last ten years.

The memorial redesigned and expanded the visitor center exhibits during the visitor center expansion project. Coverage of the political climate between Spain, Great Britain, Russia, and the United States regarding the frontier areas was added. Increased coverage of the Chinookan culture, coverage of the different Expedition members and their diverse backgrounds, profiles of Lewis and Clark, and increased emphasis on the scientific contributions has been provided. The auditorium was expanded and a multipurpose room also constructed for various functions.

With regards to how successful the park's interpretation program is, consideration must be given to the park's main audience. Most visitors do not have tremendous knowledge of the Lewis and Clark Expedition. They expect to leam more about it at the memorial. School groups and children are a large part of the memorial's audience. Discussion of more sensitive items such as the captains' regulations regarding sex with native women needs to be tempered by the interpreter for their target audience. The discussion is acceptable and expected in discussion with adult visitors, but not with a visiting fifth grade class. The park's history program must therefore be broad enough to educate children and adults.

The memorial emphasizes the positive aspects of the Expedition. Interpretation for the 1990s stresses the role of the Expedition in the development of the United States and the Pacific Northwest, as well as the natural environment and the protection it needs. There are currently six interpretive themes stressed at the park: the national significance of the Expedition, the daily life and hardships 
they faced, an appreciation of the role of the American Indians, the problem-solving abilities of the Expedition, the role of the natural environment, and Lewis and Clark as pioneering naturalists. There is an emphasis on environmental awareness. By demonstrating "the courage, fortitude, and problem-solving abilities of the Expedition", the memorial will inspire visitors "to call forth these same qualities in confronting today's challenges". ${ }^{16}$

There are variables in bringing interpretive themes to the memorial visitor. The current themes have been developed by the current superintendent and chief of interpretation. Two years from now, the memorial might have a different staff that will stress different themes. Trends in popular culture, such as environmentalism and multiculturalism, do not escape the National Park Service, often because society demands it from them. Interpretation is geared towards society's current values.

The most fundamental variable in the park's interpretation program is the individual interpreter and his or her interactions with the public. During the 1970s, memorial interpreters were learning as they went along and as they had time to research and learn more about the Expedition and the skills they were employing. For example, Curt Ahola, who was a seasonal during that time, shared a story about one of his fellow interpreters who could not start a fire with the flint and steel and decided to try and help the process by adding a little blackpowder. Needless to say, he singed his eyebrows and beard, as well as the fur on the front of his raccoon skin cap. Sometime later, a visitor showed the seasonal how to achieve his goal. Most of the memorial's interpreters go through a learning process with most 
of the skills they are demonstrating and they improve them over time. Occasionally the memorial is able to hire people already familiar with these skills, and many seasonals come back for more than one season

Currently, the memorial's Chief of Interpretation, Curt Johnson, has been at the memorial for 13 years. He is versed in the history of the Expedition and loves being at the fort in costume. He is able to have much more informative discussions with park visitors than a first year seasonal. Who the visitor finds at the fort is a major element in the overall experience the visitor has. Occasionally, the avid history buff or blackpowder expert will visit the park and be able to tell interpreters everything he or she is doing wrong, but this must be taken with a grain of salt. The interpreter will listen and acknowledge and perhaps do a little more research later.

Most visitors, in discussions with park staff or in written comments, understand that the replica is based on speculation and that only so much can be done to re-create what life was actually like for the Expedition that winter. Over and over in visitor responses, the public indicates that they appreciated the feeling of the fort replica and learning what kinds of skills were employed on the frontier. For the most part, the memorial's interpretive program provides information in an enjoyable format, something that many of the visitors have never experienced in learning history before. The most important thing that the park's interpretive program does is to stimulate the visitor's imagination. Stepping into the replica, the visitor is asked to try and imagine what it may have felt like to be there during the 
winter of 1806 . To have the opportunity to ask the public to think about history is commendable. 


\section{CONCLUSION}

The ideals of preservation, begun in the nineteenth century, centered around patriotic figures and events relevant to the development of the United States. Pride and patriotism in American heritage motivated the preservation and commemoration of battlefields, national cemeteries, homes of influential Americans, and sites relevant to frontier America and the pioneer. Since World War II, historic preservation has taken on new meanings and purposes across the nation. Preservation projects in historic districts and "neighborhoods" have become planning tools not only for preservation ideals, but economic and urban development needs as well. ${ }^{1}$ Preservation has become a complex system of standards, funding, and multipurpose projects.

The example of Fort Clatsop's entry into the National Park System as a historical unit is representative of the way many historical sites have entered the system. Movements born out of local patriotic intentions are successful when the official culture and political needs are served by a site's recognition. The political process for the creation of historic sites is a central feature of the American national preservation system, one that allows interested individuals and groups to promote what they believe to be historically significant as opposed to being told what is historically 
significant by official federal standards.

A second and equally important characteristic of the historic preservation system is the attempt to develop themes of American history by which sites can be selected. The idea that American historical periods and important events could be evenly represented in a national system was developed by the first history branch of the park service in Washington, D.C., and the first members of the advisory board appointed in 1935. Led by Verne Chatelain, these well-intentioned preservationists sought to create a working system of historic preservation across the country. However, two fundamental errors exist in this system of thematic history. To quote the Bureau historian of the National Park Service, Barry Mackintosh, the most fundamental flaw lies in the fact that "extant physical resources susceptible of being preserved and interpreted to park visitors are not equally dispersed among the major themes of history, nor are all themes equally well conveyed via such resources". ${ }^{2}$ Battlefields, forts, and historic buildings may lend to the representation of major wars, the frontier movement, or important figures in the nation's history, but the history of political climates or intellectual movements in America are not.

The second flaw in the system of thematic representation lies in the reality that the best possible historic site representative of a certain theme is not always the site that enters the system. In this case, Washington state residents felt that the site where the Expedition actually completed their mission by viewing the Pacific Ocean for the first time was more important in the realm of national recognition than Fort Clatsop. John Hussey, while stating that Fort Clatsop was nationally significant as part of the 
Expedition, felt that a survey of all Lewis and Clark sites needed to be completed and the best representative selected and added to the system. However, the political system overrode Hussey's attempt to work within the thematic system and select the best site possible. Sites committed to public memory under the National Park System, despite the attempts of the National Park Service to adequately represent American history, are not selected solely on their importance to national history. ${ }^{3}$ They are also selected under pressure from individuals, groups, and Congress, who believe the site worthy regardless of NPS standards. With Fort Clatsop, support for the site by individuals and groups was not enough to bring national recognition until 1955 when the financial and management needs of the site gave OHS more incentive to pursue national recognition. To reach that end, OHS involved Senator Richard L. Neuberger.

Senator Neuberger knew the standards of the park system and knew how to successfully approach the Fort Clatsop issue. By first passing legislation which required the Secretary of the Interior to study the feasibility of the site as a memorial, not a monument, he forced the NPS to re-evaluate the site. This step allowed Neuberger to let the NPS lead themselves to the memorial. The resulting suggested historical area report concluded that the Expedition was not adequately represented in the system, that it deserved recognition, and that the Fort Clatsop site did meet standards for a national memorial. Those conclusions gave the proposal enough legitimacy for Neuberger to write and pass the enabling legislation for the memorial. Neuberger's influence and position as chairman of the Committee on Insular and Interior Affairs gave him the power necessary to push his legislation through without 
the study Hussey recommended. The memorial was also inexpensive to establish and an acreage ceiling limited the amount and cost of land acquisitions necessary. No opposition, from inside the NPS or from other Congressmen, challenged the Fort Clatsop bill.

Once these sites have entered the park system, they are subject to interpretation by the National Park Service. Interpretation for the public is explicitly stated in the 1935 Historic Sites Act as a responsibility of the NPS. It is through programs of historic interpretation that the NPS shapes public memory in America by educating the public about historic sites and their significance in American history. Interpretation is fundamental to historic sites and serves as its primary function, to educate about American history.

Like all programs in federal agencies, interpretation has been influenced by budget cuts, political climates, and popular trends in American society, from the creation of the NPS in 1916 until the present. In 1935, Franklin D. Roosevelt wrote to Congress to promote the Historic Sites Act. In that letter, he expressed the ideal that historic interpretation "tends to enhance the respect and love of the citizen for the institutions of his country" and fosters a willingness of the citizen to give unselfishly to the causes of his country. ${ }^{4}$ Beyond the ideals of interpretation and its goal of educating the public, debate over what constitutes proper interpretation has always centered around fundamental issues. Where does interpretation fall in the realm of historic research and discourse? Who is the main audience for these programs? How do interpretive programs present historically accurate information around historic sites 
that are nothing like they were originally?

Interpreting Our Heritage by Freeman Tilden, commissioned by the park service interpretive branch in 1954 for the purpose of training and creating goals for interpreters in the park service, is the standard guide to interpretation. Tilden sets forth two basic concepts: interpretation is the revelation of a larger truth that lies behind any statement of fact and interpretation should capitalize on mere curiosity for the enrichment of the human mind and spirit. ${ }^{5}$

In reality, interpreters gear information to the average park visitor and forego the detail of more complete historical research and discourse. Through the use of different mediums such as exhibits, films, brochures, or presentations, interpreters focus around a general overview of the significance of a historic site and its relation to national history. Presentations are developed around 15-30 minute lectures designed to impart concise messages about the historic site involved. Historical research is conducted to aid in the development of historically accurate interpretation.

The Fort Clatsop replica is an example of interpretation of a historic site that is far removed from its original conditions. The concepts of re-creation have been employed not only at the fort building but in the natural surroundings as well. Outdoor museums and replications are subject to criticism for creating unreal situations. One argument states there is inherent danger in trying to freeze a period of time. The other states that periods of history can be usefully re-created to promote education in a format that is popular to the general public. The popularity of such programs also leads to the use of such sites as tourist attractions and the recognition 
that they can be economically viable.

Aside from the philosophical debate over outdoor museums, there is the opinion of the average visitor to such sites. At Fort Clatsop, park visitation has steadily increased over the years, reaching nearly a quarter of a million people in 1992. A 1986 visitor survey demonstrated that Fort Clatsop draws a broad spectrum of visitors. In 1986, twenty-seven percent of memorial visitors were under the age of twelve, twenty-six percent between the ages of 12 to 30 , twenty-seven percent between the ages of 30 to 50 , and twenty percent were 60 or older. ${ }^{6}$ Positive comments are regularly received through written visitor comments and conversations between memorial staff and visitors. Written visitor comments generally praise the knowledge level and friendliness of the memorial staff and evaluate their visit as fun and educational. $75 \%$ of all memorial visitors were family groups and, in written responses, parents applauded the educational value of the memorial for their children. The average park visitor understands that the fort is a replica and that only the idea of what the Expedition's time at the real Fort Clatsop was like can be presented. Visitors apparently enjoy the nostalgia expressed in places like Fort Clatsop and acknowledge the reality of the situation.

Interpretive programs in the park system are not static. Programs are regularly reviewed by park administrators for their effectiveness and appropriateness. More importantly, interpretive programs are influenced by the political climate and popular trends. During World War II, regional directors instructed superintendents at historic parks to emphasize the themes of freedom, democracy, and self-rule. During this time, 
the NPS reached out to the media to encourage visitation to historic sites and the celebration of those themes. During the era of the Cold War, NPS chief historian Ronald Lee expressed the need of the nation to understand its history during a time when "our basic beliefs are challenged by an alien philosophy". ${ }^{7}$ Since World War II, the Park Service, through an emphasis on American institutions and values, has served national interests through its historic sites.

One aspect of interpretation that exists at all historic sites in the system stems from the patriotic influences that fostered historic preservation in America from the beginning. Memorials and monuments are established for the purpose of honoring. For that reason, interpretation at memorials and monuments under the NPS like Fort Clatsop represent the positive aspects of history, often leaving out negative information, and center on the contributions to American development.

Public memory fluctuates, evolving from generations that established a certain site as historically significant to those generations who continue to shape the messages delivered at those sites under its continued management. The management and interpretation of national historic sites under the National Park Service is a blend of vernacular and official culture. Popular trends, most recently the emphasis on diversity and environmental education, affect the development of interpretation through visitor response and input. The needs of the official culture also affect interpretation. Those pressures are easily found during World War II and other periods of international conflict. Fort Clatsop has also been affected by trends in interpretation. During the mid-1960s, the concept of living history was developed and actively 
pursued by NPS Director George Hartzog. Mission 66, which brought the concept of the visitor center and museum exhibit to historic parks, also brought an influx of new technologies, such as audio-visual equipment. Most of the different mediums of interpretation (films, exhibits, costumed demonstration, slides, brochures, video technology, visitor activated audio stations, and wayside exhibit signs) have been incorporated into Fort Clatsop.

Historic preservation in 20th century America is influenced by standards of commemoration established by the federal system and the desires of private citizens to commemorate portions of their heritage they deem worth saving. However, patriotism is not the only motivation behind commemoration. Political influence and economic benefits (such as jobs, tourism, tax exemption, or the takeover of property as in this case) often are key factors behind such movements.

When considering the underlying factors and flaws in the system of historic preservation in America, Fort Clatsop begins to make sense. Many historians and NPS personnel would call the site historically inaccurate. There is no archeological evidence to substantiate the site and there is not enough documentation of the original fort structure to ever be able to ascertain what the building was like. The fact of the matter is that a group of individuals at an opportune moment in time had a strong connection in Congress who was able to produce national recognition for the site. The NPS then developed the site under the values and funding of Mission 66. Since 1958, Park Service managers have developed a memorial which today not only strives to commemorate the Lewis and Clark Expedition, but also exists as a research center for 
the study of it and other aspects of western history. 


\section{ENDNOTES \\ INTRODUCTION}

1. Wallace Davies, Patriotism on Parade: The Story of Veterans' and Hereditary Organizations in America, 1783-1900, (Cambridge: Harvard University Press, 1955) 215-309.

2. William J. Murtagh, Keeping Time: The History and Theory of Preservation in America, (Pittstown, N.J.: The Main Street Press, 1988), 25.

3. Murtagh, 26.

4. John L. Frisbee, "The Historic Preservation Movement in the Western United States", Norman Williams, Jr., Edmond H. Kellogg, and Frank B. Gilbert, eds., Readings in Historic Preservation: Why, What, How, (New Brunswick, N.J.: Center for Urban Policy Research, 1983), 46-47.

5. Harlan D. Unrau, and Frank G. Williss, Administrative History: Expansion of the National Park Service in the 1930s, Denver Service Center, prepared for the National Park Service, 1983, 34.

6. Murtagh, 70.

7. Unrau and Williss, 191.

8. Bodnar, 182-183.

9. Ronald A. Foresta, America's National Parks and Their Keepers, (Washington, D.C.: Resources for the Future, 1984), 77.

10. Foresta, 151

11. Murtagh, 216.

12. Murtagh, 93.

13. Charles B. Hosmer, Jr., Preservation Comes of Age: From Williamsburg to the National Trust, 1926-1949, vol 1, (Charlottesville, Virginia: University Press of Virginia, 1981), 132.

14. Murtagh, 36.

15. Unrau and Williss, 176.

16. Unrau and Williss, 166.

17. Bodnar, 196-197.

18. Current goals for interpretation, "Fort Clatsop National Memorial Information Handbook for New Employees", 7.

19. Bodnar, 13-20 


\section{ENDNOTES \\ CHAPTER ONE}

1. Precedence has been given to William Clark's plan due to his rank as captain. Expedition journals indicate that Clark developed construction plans and oversaw the construction of Fort Clatsop. Testimony from a local settler in 1900 also gives strength to Clark's floorplan.

2. Michael Silverstein, "Chinookans of the Lower Columbia", Handbook of North American Indians, vol. 7, (Washington, D.C.: Smithsonian Institute, Government Printing Office, 1990), 533.

3. Silverstein, 536-537.

4. Silverstein, 540 .

5. Silverstein, 537.

6. Gary E. Moulton, ed., The Journals of the Lewis and Clark Expedition, November 2, 1805 March 22, 1806, vol. 6, (Lincoln, Nebraska: University of Nebraska Press, 1990), 444.

7. For more information, see John A. Hussey, "Suggested Historical Area Report, Fort Clatsop Site, Oregon", prepared for the National Park Service, Region Four, April 10, 1957, 11. Additional information can be found in Ethel Abbey Moore, "Solomon Smith Built Missions", Oregon Journal, 24 July 1955, and in Rueben Gold Thwaites, ed., Original Journals of the Lewis and Clark Expedition, 1804-1806, vol. 4, 138, note 1. Early anthropological information speculates that a Clatsop village also existed at the site, which was reported by a British furtrader and navy captain in 1813.

8. Gordon B. Dodds, The American Northwest: A History of Oregon and Washington, (Arlington Heights, Illinois: The Forum Press, Inc., 1986), 35-36.

9. John A. Hussey, "Suggested Historical Area Report, Fort Clatsop Site, Oregon", prepared for the National Park Service, Region Four, April 10, 1957, 7.

10. For more information on visitation to the site in the 1800 s, see John Hussey's "Suggested Historical Area Report", including footnotes 3-16.

11. Hussey, 29.

12. Hussey, 29 .

13. Hussey, 29.

14. A copy of the transcript of the Harlan Smith interview is in the Fort Clatsop National Memorial Park Archive, National Archives and Records Center, Seattle, history files (hereafter cited as Fort Clatsop Archive). The interview was conducted by regional historian John Hussey and regional archeologist Paul Schumacher. It contains interesting rural history of the Clatsop County area during the mid to late 1800 s.

15. Hussey, 32.

16. Hussey, 32. 
17. Hussey, 33 .

18. Hussey, 33.

19. "Testimony of Carlos Shane", Proceedings of the Oregon Historical Society, 1900, Fort Clatsop Archive, 20-21

20. Hussey, 19.

21. "Hollywood Eyes Fort Clatsop", Astorian Budget, 12 February 1948, 1.

22. See the letters of Dr. Franklin Queen, Legislative History file, Fort Clatsop Archive.

23. Dr. Burt Brown Barker to Charles Peterson, 26 July 1963, Fort Clatsop Archive.

24. Minutes of Clatsop County Historical Society, 31 August 1955, Fort Clatsop Archive.

25. Wilt Paulson, former Jaycee, interview with the author, 9 December 1993.

26. Michael Foster would later serve as one of the first seasonal rangers for the Park Service at the site and in 1972 became a board member for the Fort Clatsop Historical Association, a position which he still holds.

27. Moulton, 140 .

28. Moulton, 175

29. Lancaster Pollard, Lewis and Clark at Seaside, (Seaside: Seaside Chamber of Commerce, 1954).

30. Hussey, 18.

31. "Testimony of Jennie Michel", Proceedings of the Oregon Historical Society, 1900, Fort Clatsop Archive, 22.

32. Clatsop County Deed Records, Book 71, 64. 


\section{ENDNOTES \\ CHAPTER TWO}

1. Congressional Record, 60th Cong., 1st sess., 1906, 142.

2. "A Study of Parks, Parkways and Recreational Areas of Orgeon, Vol. 1, Present Development", prepared by the State Parks Comission and the Oregon State Planning Board in conjunction with the United States Department of the Interior, National Park Service, December 1938, Fort Clatsop Archive, 29-33.

3. Chronology of the creation of Fort Clatsop National Memorial, compiled by Chief Ranger Al Stonestreet, Fort Clatsop Archive.

4. A.N. Thorndike to Senator Richard L. Neuberger, 6 February 1956, Fort Clatsop Archive.

5. Senator Richard L. Neuberger to Malcolm Bauer, 27 June 1956, Fort Clatsop Archive.

6. Congressional Record, 84th Cong., 2d sess., 1956, 9567.

7. Conrad L. Wirth to Dr. Franklin B. Queen, 16 November 1953, Fort Clatsop Archive.

8. Paul J. F. Schumacher, "Report of Archeological Excavations at Fort Clatsop National Memorial", prepared for the National Park Service, 1957.

9. John A. Hussey, telephone conversation with author, 17 December 1993.

10. Jim Thomson to Thomas Vaughan, 11 September 1968, Fort Clatsop Archive.

11. John A. Hussey to Thomas Vaughan, 19 September 1968, Fort Clatsop Archive.

12. John Miele to Regional Director, PNWR, 10 September 1973, Fort Clatsop Archive.

13. John Miele to Regional Director, Pacific Northwest Region, 6 December 1973, Fort Clatsop Archive.

14. U.S. Representative Les AuCoin to Dr. E.G. Chuinard, 23 March 1978, Fort Clatsop Archive.

15. Thomas Vaughan to Oregon Governor Robert Straub, 31 May 1978, Fort Clatsop Archive.

16. Foresta, 80-81.

17. Bodnar, 182.

18. Foresta, 149. 


\section{ENDNOTES \\ CHAPTER THREE}

1. Foresta, 52-53

2. Foresta, 54 .

3. Lawrence Merriam to NPS Director, 13 February 1958, Fort Clatsop Archive.

4. Press Release from Office of Senator Richard L. Neuberger, 22 June 1958, Fort Clatsop Archive.

5. Associate Regional Director, Region Four, to the Director, 28 December 1962, Fort Clatsop Archive.

6. Hussey, 65-74.

7. Neal Butterfield to Region Four Director, 9 September 1958, Fort Clatsop Archive.

8. Charles Peterson to Regional Director, Region Four, 20 July 1961, Fort Clatsop Archive.

9. Charles Peterson to Regional Director, Western Region, 13 July 1963, Fort Clatsop Archive.

10. Carl Parcher Russell worked for the Park Service for 34 years, 1923 to 1957. During that time he served as the Chief of the museum division, the wildlife division, and as the Chief Naturalist. He also served as Director of Region One and as Superintendent of Yosemite National Park. Just prior to his retirement, Russell served as the Coordinator of Research and Interpretation, Region Four. Russell specialized in the history of the fur trade and the everyday life of the frontier. Russell provided documentation for historical interpretation of frontier and pioneer life for the park service and other agencies. The Region Four office contracted Russell to complete the historical data for the Fort Clatsop structure, as well as the first exhibit plan for the visitor center.

11. John A. Hussey and Carl P. Russell, "Historic Structures Report and Furnishing Plan, Fort Clatsop Replica, Fort Clatsop National Memorial", Part I, prepared for the National Park Service, Region Four, December 1959, a.

12. Hussey and Russell, 35.

13. Hussey and Russell, 43-44.

14. Harold G. Fowler, "Landscape Data, Historic Structures Report and Furnishing Plan, Fort Clatsop Replica, Fort Clatsop National Memorial", Part I, prepared for the National Park Service, 1959, 85.

15. Lyle E. Bennett, Supervisory Architect, WODC, to the Regional Director, Region Four, 29 January 1960, Fort Clatsop Archive.

16. Charles L. Peterson and Burnby Bell, "Historic Structures Report and Furmishing Plan, Fort Clatsop Replica, Fort Clatsop National Memorial", Part II, prepared for the National Park Service, 1962,3 . 
17. Cynthia Orlando, "Superintendent's Annual Report, Fort Clatsop National Memorial", 1990, Fort Clatsop Archive.

18. Charles Peterson, "Master Plan of Fort Clatsop National Memorial", 3.

19. Charles Peterson, "Superintendent's Annual Report, Fort Clatsop National Memorial", 1963, Fort Clatsop Archive.

20. James Thomson, interview by the author, 10 November 1993.

21. James Thomson, interview by the author, 10 November 1993.

22. James Thomson, interview by the author, 10 November 1993.

23. Paul Haertel, interview by the author, 7 December 1993.

24. Paul Haertel, "Superintendent's Annual Report, Fort Clatsop National Memorial", 1972.

25. Jane T. Merritt, The Administrative History of Fort Vancouver National Historic Site, prepared for the National Park Service, Pacific Northwest Region, 1993, 101.

26. "Annual Report of Cooperating Associaiton, 1974", Fort Clatsop Historical Association.

27. Merritt, 101.

28. Sandy Reinbach, interview by the author, 8 January 1994.

29. FCHA was able to purchase a portion of Robert Lange's personal library regarding the Lewis and Clark Expedition and western history. Robert Lange was a member of the Lewis and Clark Trail Heritage Foundation Committee and an influential member of Oregon Lewis and Clark groups. He assisted the memorial in research and development of their costumed demonstration programs. Total, FCHA purchased many volumes, some of Lange's personal papers, minutes from trail heritage committee meetings, artifacts from the 1905 Lewis and Clark Exposition, and many other items. 


\section{ENDNOTES \\ CHAPTER FOUR}

1. Bodnar, 175-179.

2. Freeman Tilden, Interpreting Our Heritage, (Chapel Hill: University of North Carolina Press, 1977), 7-8.

3. Charles Peterson, "Superintendent's Annual Report, Fort Clatsop National Memorial", 1964, Fort Clatsop Archive.

4. Barry Mackintosh, Interpretation in the National Park Service: A Historical Perspective, prepared for the National Park Service, History Division, 1986, 23.

5. Gary E. Moulton, ed., The Journals of the Lewis and Clark Expedition, November 2, 1805-March 22, 1806, Volume Six, (Lincoln: University of Nebraska Press, 1990), 156-158.

6. Moulton, 200-201.

7. Moulton, 186.

8. Moulton, 223-224.

9. David Lavender, The Way To the Western Sea: Lewis and Clark Across the Continent, (New York: Doubleday, 1988), 273.

10. "Interpretive Prospectus, Fort Clatsop National Memorial", prepared for the National Park Service, 1975.

11. Interviews with former park staff by the author, September 1993 through August 1994.

12. Frank Walker, interview by the author, 3 November 1993.

13. Letter from Scott Eckberg to author, 1 August 1994.

14. Scott Eckberg, former interpretive specialist at Fort Clatsop National Memorial, interview by the author, 20 April 1994.

15. Barbe Minard, former seasonal ranger at Fort Clatsop National Memorial, interview by the author, 20 May 1994.

16. "Fort Clatsop National Memorial Information Handbook for New Employees", 7. 


\section{ENDNOTES \\ CONCLUSION}

1. Nathan Weinberg, Preservation in American Towns and Cities, (Boulder, Colorado: Westview Press, 1979), 213-214.

2. Barry Mackintosh, Interpretation in the National Park Service: A Historical Perspective, prepared for the National Park Service, History Division, 1986, 34-35.

3. For more information on the difficulty of the system of thematic representation see also Richard W. Sellars and Melody Webb, An Interview with Robert M. Utley on the History of Historic Preservation in the National Park Service--1947-1980, Professional Papers No. 16, prepared for the National Park Service, Southwest Cultural Resources Center, 1985. Utley speaks frankly about the problems inherent in selection of themes in history.

4. Mackintosh, 23 .

5. Tilden, 8 .

6. Marty E. Lee, et al., "1986 Fort Clatsop Visitor Survey", Fort Clatsop Archive.

7. Mackintosh, 77. 


\section{BIBLIOGRAPHY}

\section{PRIMARY SOURCES}

Fort Clatsop National Memorial Park Archive, National Archives and Records Center, Seattle. The primary resource for this thesis is the Fort Clatsop National Memorial Park Archive compiled by the author in 1993. This archive includes materials from the records of Fort Clatsop National Memorial; the Pacific Northwest Regional Office of the NPS, Seattle, Washington; the Western Regional Office of the NPS, San Francisco, California; National Archives and Records Centers, Seattle, Washington and San Bruno, California; Oregon Historical Society Manuscripts Library; and the papers of Senator Richard L. Neuberger, University of Oregon Library. Interviews conducted by the author of former members of the Jaycees, Thomas Vaughan of the Oregon Historical Society, and the past and current staff of the memorial have also provided material about Fort Clatsop.

Sellars, Richard and Melody Webb. An Interview with Robert M. Utley on the History of Historic Preservation in the National Park Service--1947-1980. Professional Papers No. 16. National Park Service, Southwest Cultural Resources Center, 1985.

\section{SECONDARY SOURCES}

Secondary resource materials useful in providing a background on historic preservation, public memory, and the Lewis and Clark Expedition are as follows: Blatti, Jo, ed. Past Meets Present: Essays About Historic Interpretation and Public Audiences. Washington, D.C.: Smithsonian Institution Press, 1987. 
Bodnar, John. Remaking America: Public Memory, Commemoration, and Patriotism in the Twentieth Century. Princeton, N.J.: Princeton University Press, 1992.

Davies, Wallace Evan. Patriotism on Parade: The Story of Veterans' and Hereditary Organizations in America, 1783-1900. Cambridge, Mass.: Harvard University Press, 1955.

Dodds, Gordon B. The American Northwest: A History of Oregon and Washington. Arlington Heights, Illinois: The Forum Press, Inc., 1986.

Foresta, Ronald A. America's National Parks and Their Keepers. Washington, D.C.: Resources for the Future, 1984.

Hosmer, Charles B., Jr. Preservation Comes of Age: From Williamsburg to the National Trust, 1926-1949. 2 vols. Charlottesville, Virginia: University Press of Virginia, 1981.

Lamme, Ary J., III. America's Historic Landscapes: Community Power and the Preservation of Four National Historic Sites. Knoxville, Tennessee: University of Tennessee Press, 1989.

Lavender, David. The Way to the Western Sea: Lewis and Clark Across the Continent. New York: Doubleday, 1988.

Mackintosh, Barry. The Historic Sites Survey and National Historic Landmarks Program: A Survey. National Park Service, History Division, 1985.

--- Interpretation in the National Park Service: A Historical Perspective. National Park Service, History Division, 1986.

---. The National Historic Preservation Act and the National Park Service: A History. 
National Park Service, History Division, 1986.

Merritt, Jane. Administrative History: Fort Vancouver National Historic Site. National Park Service, Pacific Northwest Region, Cultural Resources Division, 1993.

Moulton, Gary E. The Journals of the Lewis and Clark Expedition, Vol. 6, November 2, 1805-March 22, 1806. Lincoln, Nebraska: University of Nebraska Press, 1990.

Murtagh, William J. Keeping Time: The History and Theory of Preservation in America. Pittstown, N.J.: The Main Street Press, 1988.

Preservation Forum 2(Fall 1988). Issue dedicated to historic sites and tourism. The Public Historian 9(Spring 1987)2. Issue on the National Park Service and preservation.

Rothman, Hal. Preserving Different Pasts: The American National Monuments. Urbana, Illinois: University of Illinois Press, 1989.

Runte, Alfred. National Parks: The American Experience. $2 \mathrm{~d}$ ed. Lincoln, Nebraska: University of Nebraska Press, 1987.

Tilden, Freeman. Interpreting Our Heritage. 2d ed. Chapel Hill, North Carolina: University of North Carolina Press, 1977.

Unrau, Harlan D. and G. Frank Williss. Administrative History: Expansion of the National Park Service in the 1930s. National Park Service, Denver Service Center, 1983.

Weinberg, Nathan. Preservation in American Towns and Cities. Boulder, Colorado: Westview Press, 1979.

Williams, Norman, Jr., Edmond H. Kellogg, and Frank B. Gilbert. Readings in 
Historic Preservation Why? What? How? New Brunswick, N.J.: Center for Urban Policy Research, 1983. 